\title{
Predators and parasitoids of the harlequin ladybird, Harmonia axyridis, in its native range and invaded areas
}

\author{
Piotr Ceryngier $(\mathbb{D} \cdot$ Oldřich Nedvěd • Audrey A. Grez • Eric W. Riddick • \\ Helen E. Roy • Gilles San Martin • Tove Steenberg • Petr Veselý • \\ Tania Zaviezo $\cdot$ Álvaro Zúñiga-Reinoso $\cdot$ Danny Haelewaters
}

Received: 14 May 2017 / Accepted: 27 October 2017/Published online: 30 October 2017

(C) The Author(s) 2017. This article is an open access publication

\begin{abstract}
The harlequin ladybird Harmonia axyridis (Coleoptera: Coccinellidae) has rapidly spread in several continents over the past 30 years and is considered an invasive alien species. The success of $H$. axyridis as an invader is often attributed to weak control by natural enemies. In this paper, we provide an overview of current knowledge on predators and parasitoids of $H$. axyridis. The common feature of predators and parasitoids is that they directly kill exploited organisms. Currently available data show
\end{abstract}

P. Ceryngier $(\square)$

Faculty of Biology and Environmental Sciences, Cardinal Stefan Wyszyński University, Wóycickiego 1/3,

01-938 Warsaw, Poland

e-mail: p.ceryngier@uksw.edu.pl

O. Nedvěd · P. Veselý

Faculty of Science, University of South Bohemia, Branišovská 1760, 37005 České Budějovice, Czech

Republic

O. Nedvěd

Institute of Entomology, Academy of Sciences of the Czech Republic, Branišovská 31,

37005 České Budějovice, Czech Republic

A. A. Grez

Facultad Ciencias Veterinarias y Pecuarias, Universidad de Chile, Casilla 2 Correo 15, La Granja, Santiago, Chile

E. W. Riddick

USDA-ARS, Jamie-Whitten Delta States Research

Center, 59 Lee Road, Stoneville, MS 38776, USA that $H$. axyridis, displaying a variety of chemical, mechanical, and microbiological anti-predator defenses, is usually avoided by predators. However, some birds and invertebrates can eat this ladybird without harmful consequences. The primary defenses of $H$. axyridis against parasitoids include immune response and physiological and nutritional unsuitability for parasitoid development. These defenses are probably relatively efficient against most ladybird parasitoids, but not against flies of the genus

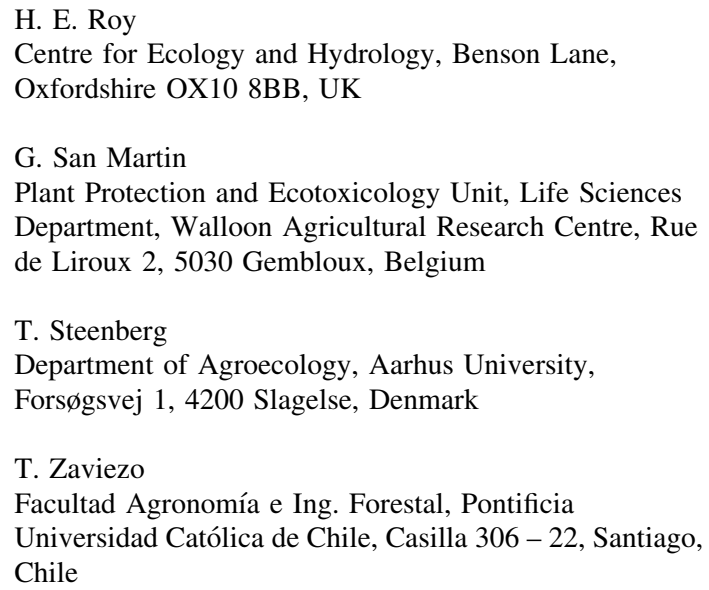

Á. Zúñiga-Reinoso

Laboratorio de Genética y Evolución, Facultad de Ciencias, Universidad de Chile, Las Palmera 3425, 7800003 Ñuñoa, Santiago, Chile 
Phalacrotophora. The latter are idiobiont parasitoids and hence can evade the host's immune response. Indeed, rates of parasitism of $H$. axyridis by Phalacrotophora in the Palaearctic region (both in the native range in Asia and in Europe) are relatively high. While strong evidence for enemy release on the invasive populations of $H$. axyridis is lacking, several cases of parasitoid acquisition have been recorded in Europe, North America, and South America. We conclude that enemy release cannot be excluded as a possible mechanism contributing to the spread and increase of $H$. axyridis in the early stages of invasion, but adaptation of parasitoids may lead to novel associations which might offset previous effects of enemy release. However, further work is required to elucidate the population-level effects of such interactions.

Keywords biocontrol · Coccinellidae $\cdot$ Enemy acquisition $\cdot$ Enemy release $\cdot$ Natural enemies

\section{Introduction}

The harlequin ladybird Harmonia axyridis (Pallas) is a species of Asiatic origin that became invasive in the late 1980s in North America and subsequently in other continents. Until now $H$. axyridis has colonized extensive areas in North and South America, Europe, and to a lesser extent Africa (Brown et al. 2011; Roy et al. 2016; Camacho-Cervantes et al. 2017). It has started to spread in some parts of western Asia (Orlova-Bienkowskaja 2014; Ukrainsky and OrlovaBienkowskaja 2014; Bukejs and Telnov 2015; Görür et al. 2015; Roy et al. 2016) and New Zealand (https:// www.mpi.govt.nz/document-vault/12261). In its invaded areas, $H$. axyridis can quickly become very common, posing a threat to native insect communities, especially to other ladybirds (Roy et al. 2012, 2016; Grez et al. 2016). It can also cause economic losses in horticulture and winemaking, as well as become a nuisance and health problem to some people (Koch and Galvan 2008; Roy et al. 2016). Nevertheless, $H$.

D. Haelewaters

Department of Organismic and Evolutionary Biology, Harvard University, 22 Divinity Avenue, Cambridge, MA 02138, USA axyridis is a highly effective predator of aphids in several cropping systems, especially soybean, pecan, and apple (Riddick 2017). There are emerging anecdotal reports of the success of this species in controlling pest insects in fruit crops in the UK.

The success of $H$. axyridis as an invader is often attributed to weak control of its populations by natural enemies, with the enemy release hypothesis (ERH) usually being quoted to explain this low level of biological control (Roy et al. 2008, 2011a, b; Berkvens et al. 2010; Firlej et al. 2012; Comont et al. 2014; Haelewaters et al. 2017). ERH states that an alien species invading a new geographic range will be less affected by natural enemies compared to native species, leading to population build-up of the alien species in its invasive range. It remains disputable, however, whether or not the enemy release is responsible for fast expansion of $H$. axyridis with frequently observed population outbreaks. Some evidence exists that the invasive $H$. axyridis may be less affected by enemies than native ladybirds (Shapiro-Ilan and Cottrell 2005; Koyama and Majerus 2008; Roy et al. 2008; Comont et al. 2014). However, it is often uncertain whether this is the effect of enemy release or of generally low susceptibility of $H$. axyridis to most enemies.

This review focuses on predators and parasitoids of $H$. axyridis. These two categories of natural enemies differ in many respects but are similar in that that both usually directly kill exploited organisms rather than decrease their fecundity or other fitness parameters. The group of enemies of $H$. axyridis, in which sublethal fitness effects prevail over direct killing, i.e. multicellular true parasites, has recently been reviewed by Haelewaters et al. (2017). Here, we (1) compile the available data on the predators and parasitoids of $H$. axyridis in its native range and invaded areas, (2) analyze the importance of these enemies in limiting populations of $H$. axyridis, (3) discuss enemy release and enemy acquisition by invading $H$. axyridis, and (4) suggest future research directions concerning this topic. In addition, we conducted a meta-analysis of data from 21 studies about Dinocampus coccinellae and Phalacrotophora spp. in the literature and unpublished data. Based on the available data, we only analyzed rates of parasitism (and emergence in the case of $D$. coccinellae) between the native area of $H$. axyridis and its invaded regions, between different ladybird species, and over 
time. The data used, $\mathrm{R}$ code, and report of the results from the meta-analysis are available for download from the figshare online repository (San Martin 2017).

\section{Predators of Harmonia axyridis}

Due to their toxic properties and low palatability, ladybirds in general are rarely attacked by predators. For many species, including $H$. axyridis, aposematic colouration and intense smell of pyrazines provide additional protection from predation (Daloze et al. 1995; Pasteels 2007; Ceryngier et al. 2012; Pettersson 2012). Nevertheless, some animals can eat ladybirds, and these are usually generalist predators. The predators can be either intraguild or extraguild but the distinction, however, is not always obvious, because the guilds of many ladybirds and other predators may change depending on the season and food availability. Harmonia axyridis, for example, may switch among various kinds of prey or plant food (pollen, nectar, fruit) (Koch 2003; Lucas 2012). Many aphids and other hemipterans (Adelgidae, Psyllidae, Aleyrodidae), and even pollen were found to be essential food for this species (Berkvens et al. 2008; Hodek and Honĕk 2009; Hodek and Evans 2012). Despite this broad polyphagy, $H$. axyridis can be regarded as principally aphidophagous (Koch 2003), and therefore we restrict the usage of the term "intraguild predators of $H$. axyridis" to other primarily aphidophagous species that can also prey on $H$. axyridis.

While determining the prevalence rates of pathogens, parasites and parasitoids in populations of their hosts is relatively simple, the rates of predation are difficult to measure (Naranjo and Hagler 2001; Michaud and Harwood 2012). Most frequently only qualitative assessment of the diet of predators has been determined, either through direct observation of predation events or identification of prey remnants in predator's alimentary tract or faeces (Harwood and Obrycki 2005; Michalski et al. 2011). An attempt to quantify the effect of invertebrate predators on $H$. axyridis and the two-spot ladybird, Adalia bipunctata (L.), was made in northern Italy by Burgio et al. (2008). Using outdoor cage experiments, they found that the rate of predation on $H$. axyridis eggs did not exceed $2 \%$, while up to $40 \%$ of the eggs of $A$. bipunctata were consumed or destroyed. Individual larval instars, however, were preyed on at similar rates in both species. The cage method (sensu Burgio et al.
2008) can provide some estimation of the overall predation but it cannot indicate with certainty which predators are involved. The effectiveness and prey preference of individual predators are often assessed in laboratory experiments, and this also applies to predation on ladybirds, including $H$. axyridis (HoughGoldstein et al. 1996; Yasuda and Kimura 2001; De Clercq et al. 2003; Santi and Maini 2006; Sloggett 2010a; Průchová et al. 2014; Veselý et al. 2016).

\section{Extraguild predators}

Extraguild predation on Coccinellidae has been studied relatively often in birds (Ceryngier et al. 2012). However, bird predation specifically on $H$. axyridis has been rarely reported. In the Far East of Russia, within its native range, $H$. axyridis was reported to be eaten by eight bird species (Nechayev and Kuznetsov 1973). In sites of its mass overwintering aggregations in the Far East it was eaten frequently by the greyheaded woodpecker, Picus canus J. F. Gmelin (Piciformes: Picidae) and the Eurasian nuthatch, Sitta europaea L. (Passeriformes: Sittidae) (Kuznetsov 1997). In the invasive range (Poland), H. axyridis was found to be preyed upon by house martins, Delichon urbica (L.) (Passeriformes: Hirundinidae), but much less frequently compared to native ladybirds (Electronic Appendix to Orłowski and Karg 2013). A single case of predation of $H$. axyridis by the black redstart, Phoenicurus ochruros (S. G. Gmelin) (Passeriformes: Muscicapidae) was reported by Romanowski and Ceryngier (2016).

Experimental studies showed that some birds, like the great tit, Parus major L. (Passeriformes: Paridae), strongly avoid attacking $H$. axyridis, both the red-andblack succinea form (Průchová et al. 2014) and the melanic spectabilis form (Veselý and Nedvěd, unpublished data). However, there were some attacks observed towards ladybirds modified by colour painting: $10 \%$ of $H$. axyridis were attacked when they were coloured brown with black spots and 25\% were attacked when coloured brown without spots (Průchová et al. 2014). In contrast to great tits, tree sparrows, Passer montanus (L.) (Passeriformes: Passeridae), commonly attack $H$. axyridis as shown by Veselý et al. (2016). Naïve as well as experienced, adult sparrows attacked the succinea form as often as the brown-painted form. Furthermore, while great tits never killed or consumed any ladybird of several 
species (Dolenská et al. 2009), including H. axyridis (Průchová et al. 2014), tree sparrows consumed $H$. axyridis (usually in a series of five individuals) showing no sign of discomfort or nausea (Veselý et al. 2016). Tree sparrows are obviously adapted to ingesting ladybirds and coping, physiologically, with their alkaloids and pyrazines.

Published data on predation of $H$. axyridis by vertebrates other than birds are lacking. There is an unpublished record of rodent predation on overwintering $H$. axyridis. In the vicinity of České Budějovice (Czech Republic), R. Vítek (pers. comm.) found elytra and wings of several tens of $H$. axyridis adults in an empty bee hive. As the hive was observed to be visited by the wood mouse (Apodemus sylvaticus (L.)), it is assumed that the beetles were preyed upon by this species.

Available data on invertebrates preying upon $H$. axyridis, albeit few and scattered, point at spiders and heteropteran bugs as the main predators in this category (Table 1). Both web-building (Araneidae, Pholcidae, Theridiidae) and actively hunting spiders (Oxyopidae, Philodromidae, Thomisidae) have been recorded consuming $H$. axyridis. However, some data indicate that $H$. axyridis is rather avoided by certain spiders, even if they prey on other ladybirds. Laboratory studies by Yasuda and Kimura (2001) demonstrated that Ebrechtella tricuspidata (F.) (Thomisidae) hunts larvae of Coccinella septempunctata L. and Propylea japonica (Thunberg) but not those of $H$. axyridis. In contrast, Araneus diadematus Clerck (Araneidae) readily consumed both $C$. septempunctata and $H$. axyridis and chemical defences of these ladybirds had little deterrent or toxic effects on the spider (Sloggett 2010a, b). Another example of a spider that does not avoid $H$. axyridis as a prey is Steatoda nobilis (Thorell) (Theridiidae). This species, native to the Canary Islands and Madeira and invasive in Europe and North America, is since 2015 established in southern Chile (Taucare-Ríos et al. 2016) and has been found as a relatively frequent predator of $H$. axyridis soon after establishment. While numbers of H. axyridis in Concepción (Chile) rapidly increased in 2015, ladybirds were found trapped in webs of $S$. nobilis and the spiders were observed to prey on $H$. axyridis. Of 19 spider webs recorded by Á. ZúñigaReinoso et al. (unpublished data), eleven contained 21 corpses of $H$. axyridis (1-3 corpses per web). Other ladybird species, such as the native Eriopis eschscholtzii Mulsant and the introduced Adalia bipunctata were also found in the webs, however, in much lower frequencies and always a single specimen per web. In 2016, S. nobilis individuals preying on $H$. axyridis were observed in Temuco, about $220 \mathrm{~km} \mathrm{SE}$ of Concepción (F. Téllez, pers. comm.), in Pucón, about $290 \mathrm{~km}$ SE of Concepción (A. Grez, unpublished data, Fig. 1), and in Valdivia, about $335 \mathrm{~km} \mathrm{~S}$ of Concepción (O. Cerna, pers. comm.). These observations represent an interesting case of one invasive alien species providing some degree of limitation of the other invasive alien species.

Laboratory experiments with predatory Heteroptera again showed that some species accept and some reject $H$. axyridis as a food source. De Clercq et al. (2003) found that the older instars and adults of the pentatomid Podisus maculiventris (Say) readily preyed on eggs and larvae of $H$. axyridis but rarely attacked adult beetles. Larvae of $H$. axyridis were less suitable and less preferred food for nymphs of the bug than the caterpillars of the noctuid Spodoptera littoralis (Boisduval) and the pyralid Galleria melonella (L.) moths, but much more suitable than the aphid Myzus persicae (Sulzer). Podisus maculiventris often successfully hunted $H$. axyridis, while the opposite outcomes of this interaction were not observed. Santi and Maini (2006) discovered that adults of the anthocorid Orius laevigatus (Fieber) rejected eggs of $H$. axyridis as well as of Adalia bipunctata. In the field in central Chile, the assassin bug Zelus renardii Kolenati (Reduviidae) preyed on H. axyridis. Interestingly, this is another case where one invasive alien species is found preying on another invasive alien species, both of which being associated with anthropogenic habitats (Faúndez 2015; Grez et al. 2016).

\section{Intraguild predators}

While much has been written about $H$. axyridis as an efficient intraguild predator (e.g. Yasuda and Ohnuma 1999; Yasuda et al. 2004; Pell et al. 2008; Ware and Majerus 2008; Raak-van den Berg et al. 2012), little data is available on $H$. axyridis as an intraguild prey. Indeed, in experiments testing the outcomes of intraguild interactions involving $H$. axyridis, it usually appears superior to other aphidophagous predators (Yasuda and Ohnuma 1999; Yasuda et al. 2004; Ware and Majerus 2008; Raak-van den Berg et al. 2012; 


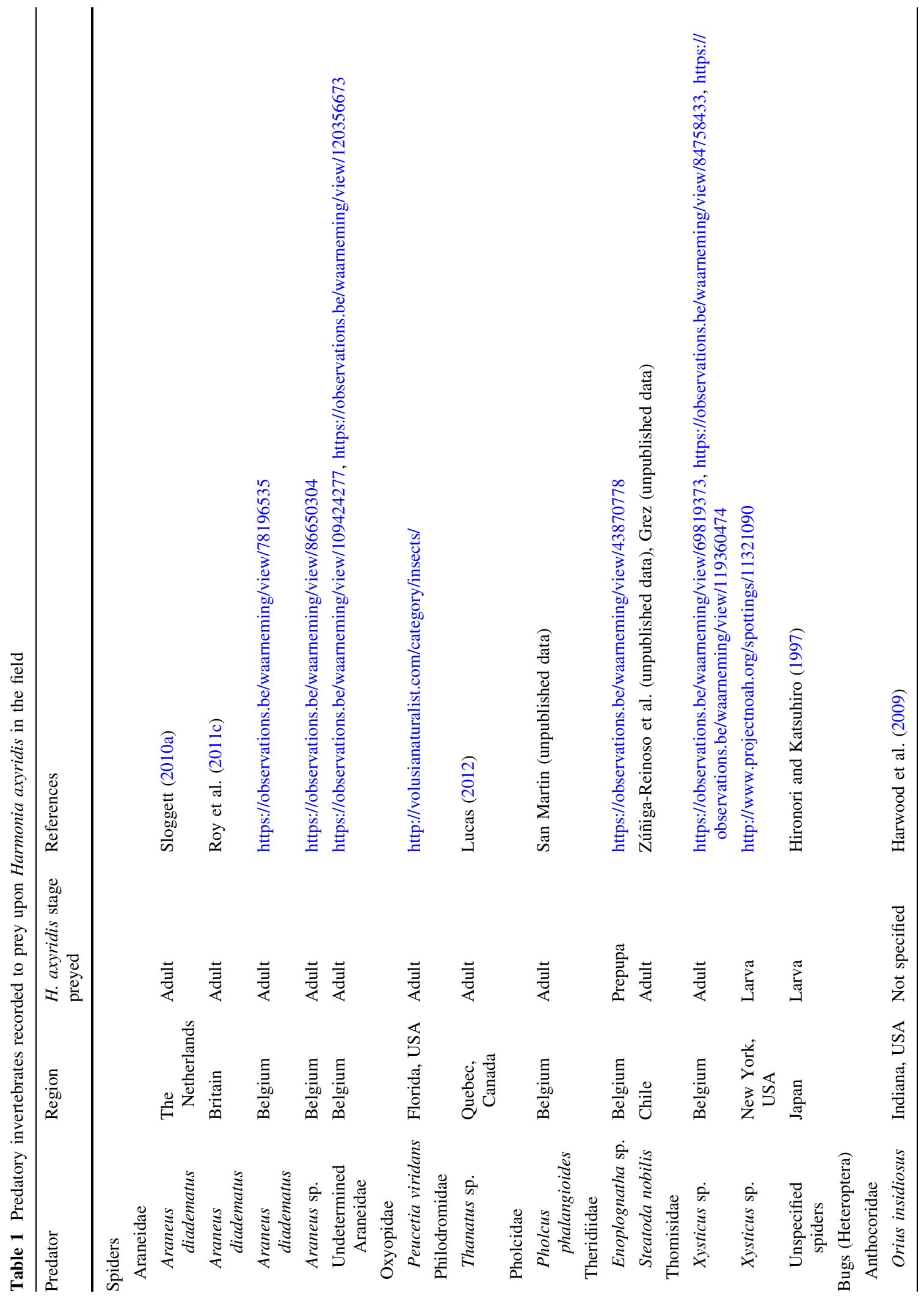




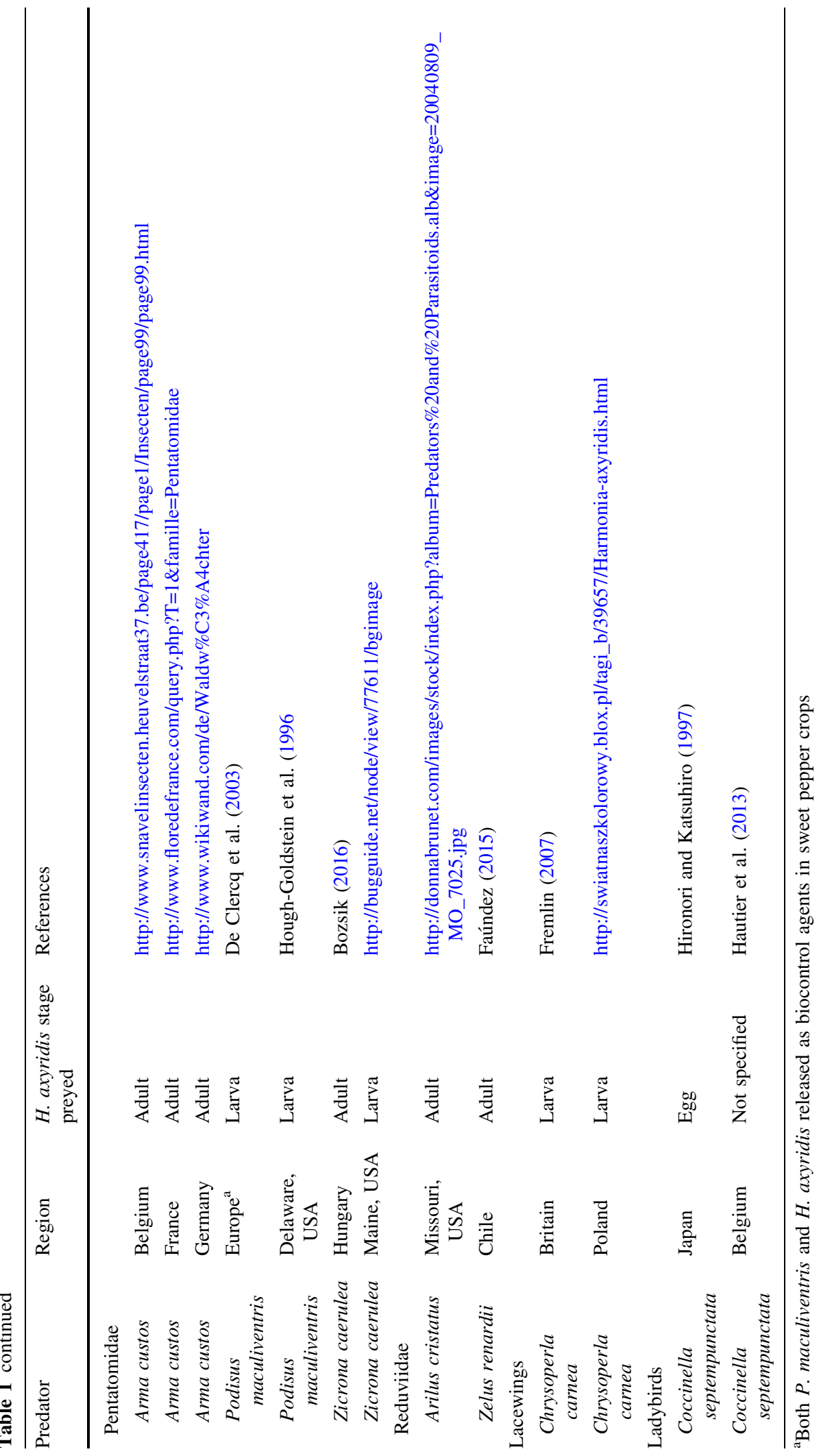




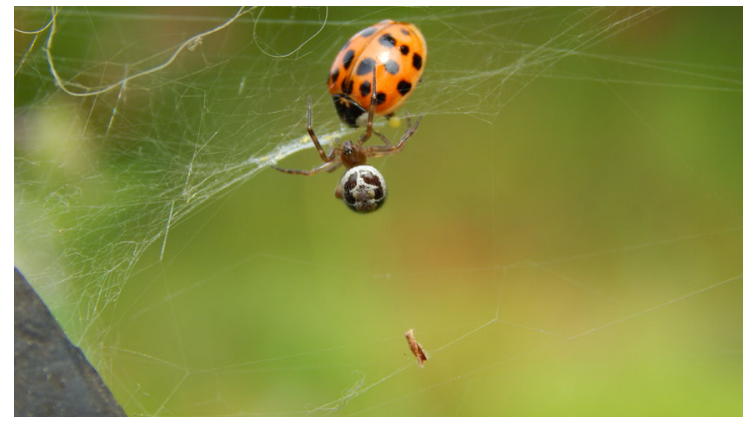

Fig. 1 Steatoda nobilis preying upon Harmonia axyridis (Pucón, Chile, 27th September 2016, photographed and reported via www.chinita-arlequin.uchile.cl by Miguel Ángel Mellado)

Katsanis et al. 2013). A few exceptions include larvae of the ladybird Anatis ocellata (L.) (Ware and Majerus 2008; Katsanis et al. 2013) and of the lacewings Chrysoperla carnea (Stephens) (Nedvĕd et al. 2010, 2013) and C. rufilabris (Burmeister) (Michaud and Grant 2003). Larvae of A. ocellata are covered with sclerotized spines and, additionally, are larger than larvae of $H$. axyridis of the same instar. These features seem to result in unidirectional IGP for encounters between $H$. axyridis and A. ocellata in which the latter dominates. The importance of spiny larval projections for anti-predator defence and probability to win in intraguild confrontation was further demonstrated by Ware and Majerus (2008) and Katsanis et al. (2013). They found that spiny larvae of other ladybird species, such as Calvia quatuordeciguttata (L.) or Harmonia quadripunctata (Pontoppidan), although often preyed upon by larvae of $H$. axyridis, relatively frequently played a role of intraguild predators of the latter.

In laboratory experiments it has been shown that lacewing larvae can efficiently kill even large larvae of $H$. axyridis, although sclerotized spines are missing in the former. Instead, these lacewing larvae are equipped with very long and sharp jaws that deter predators from attacking them and, on the other hand, enable them to effectively attack predators (Michaud and Grant 2003; Nedvěd et al. 2010, 2013; Wells et al. 2017). Larvae of $C$. carnea have also been observed preying on the larvae of $H$. axyridis in the field (Fremlin 2007, Table 1).
Parasitoids of Harmonia axyridis

Most parasitoids recorded from $H$. axyridis are restricted in their host use to species of Coccinellidae. Known exceptions include polyphagous tachinid flies of the genera Medina and Strongygaster. A complete list of parasitoids of $H$. axyridis in its native range and invaded areas is given in Table 2.

\section{Phalacrotophora spp. (Diptera: Phoridae)}

The polyphyletic genus Phalacrotophora has a worldwide distribution and comprises over 50 described species (Disney 2012), of which nine have been recorded as gregarious parasitoids of the pupae of ladybirds in the tribe Coccinellini, and less often Chilocorini (Ceryngier et al. 2012). Five species parasitize $H$. axyridis. These are $P$. berolinensis Schmitz, $P$. beuki Disney, $P$. delageae Disney, $P$. fasciata (Fallén), and $P$. philaxyridis Disney (Table 2). For one of them, P. philaxyridis, H. axyridis is the only known host so far (Disney 1997). However, as this fly is only known from the few Japanese specimens of the original species description, it is difficult to say how widespread or host-specific it is. The other species of Phalacrotophora known to occur within the native range of $H$. axyridis are $P$. fasciata, $P$. decimaculata Liu, and $P$. quadrimaculata Schmitz (Ceryngier et al. 2012). Phalacrotophora fasciata was discovered in H. axyridis in Western Siberia and Far East of Russia (Filatova 1974; Kuznetsov 1975, 1987, 1997). Phalacrotophora decimaculata was found in Shaanxi province (central China) in an unidentified ladybird, and $P$. quadrimaculata was found in Guangdong province (SE China) without any host association (Liu 2001). The only known host of the latter species was recorded in New Caledonia. This is the imported (American) Olla v-nigrum (Mulsant) (Disney and Chazeau 1990). Several reports from continental Asia and Japan (Maeta 1969a; Osawa 1992; Park et al. 1996) mention parasitism of $H$. axyridis by undetermined species of Phalacrotophora.

Phalacrotophora have also been found in ladybirds within the areas invaded by $H$. axyridis, in Europe and South America (Ceryngier et al. 2012). In Europe, the members of four species are frequent parasitoids of ladybirds, including $H$. axyridis (Table 2), while in South America, P. nedae (Malloch) is known to 
Table 2 Records of parasitoids of Harmonia axyridis

\begin{tabular}{|c|c|c|c|c|c|}
\hline & Native range & $\begin{array}{l}\text { North } \\
\text { America }\end{array}$ & $\begin{array}{l}\text { South } \\
\text { America }\end{array}$ & Europe & Africa \\
\hline \multicolumn{6}{|l|}{ Diptera: Phoridae } \\
\hline $\begin{array}{c}\text { Phalacrotophora } \\
\text { berolinensis }\end{array}$ & & & & $3,7,34,35,41$ & \\
\hline Phalacrotophora beuki & & & & 7 & \\
\hline Phalacrotophora delageae & & & & 2,7 & \\
\hline Phalacrotophora fasciata & $8,19,20,21$ & & & $3,7,10,26,34,35,41$ & \\
\hline $\begin{array}{c}\text { Phalacrotophora } \\
\text { philaxyridis }\end{array}$ & 5 & & & & \\
\hline Phalacrotophota sp. & $24,30,31$ & & & 38 & \\
\hline \multicolumn{6}{|l|}{ Diptera: Tachinidae } \\
\hline Medina separata & & & & 36 & \\
\hline Medina sp. $^{\mathrm{a}}$ & $19,20,31$ & & & & \\
\hline Strongygaster brasiliensis & & & 39 & & \\
\hline Strongygaster triangulifera & & $15,28,29$ & & & \\
\hline \multicolumn{6}{|l|}{ Hymenoptera: Braconidae } \\
\hline Dinocampus coccinellae & $\begin{array}{l}8,16,17,23,25 \\
31\end{array}$ & $9,14,15,22$ & 36,39 & $1,4,6,10,12,13,18,32,37,38,41$ & 27,35 \\
\hline \multicolumn{6}{|c|}{ Hymenoptera: Eulophidae, Tetrastichinae } \\
\hline Aprostocetus neglectus & & 33 & & & \\
\hline Oomyzus scaposus & $8,20,21$ & 33 & & 3,41 & \\
\hline undet. Tetrastichinae ${ }^{\mathrm{b}}$ & 19 & & & 34 & \\
\hline \multicolumn{6}{|l|}{ Hymenoptera: Encyrtidae } \\
\hline Homalotylus sp. ${ }^{\mathrm{c}}$ & 21,40 & & & 11,36 & \\
\hline Homalotylus terminalis & & 33 & & & \\
\hline \multicolumn{6}{|l|}{ Hymenoptera: Pteromalidae } \\
\hline Pachyneuron altiscuta ${ }^{\mathrm{d}}$ & & 33 & & & \\
\hline Pachyneuron sp. ${ }^{\mathrm{e}}$ & 20 & & & & \\
\hline
\end{tabular}

References: 1-Berkvens et al. (2010), 2-Ceryngier et al. (2012), 3-Comont et al. (2014), 4-Dindo et al. (2016), 5-Disney (1997), 6-Drumont (2011), 7-Durska and Ceryngier (2014), 8-Filatova (1974), 9—Firlej et al. (2005), 10—Francati (2015), 11— Glavendekić et al. (2010), 12-Hall et al. (2009), 13-Herz and Kleespies (2012), 14-Hoogendoorn and Heimpel (2002), 15Katsoyannos and Aliniazee (1998), 16-Kawauchi (1984), 17-Koide (1961), 18-Koyama and Majerus (2008), 19-Kuznetsov (1975), 20—Kuznetsov (1987), 21—Kuznetsov (1997), 22—LaMana and Miller (1996), 23—Liu (1950), 24-Maeta (1969a), 25Maeta (1969b), 26-Michie et al. (2009), 27-Minnaar et al. (2014), 28-Nalepa and Kidd (2002), 29-Nalepa et al. (1996), 30Osawa (1992), 31-Park et al. (1996), 32-Raak-van den Berg et al. (2014), 33-Riddick et al. (2009), 34-Rondoni et al. (2013), 35-Roy et al. (2011b), 36-Roy et al. (2016), 37-Steenberg and Harding (2009), 38-Steenberg and Harding (2010), 39-Togni et al. (2015), 40-Trjapitzin (2011), 41-Ware et al. (2010)

${ }^{a}$ Reported as Degeeria (= Medina) luctuosa (probably M. separata)

${ }^{\mathrm{b}}$ Probably Oomyzus scaposus

${ }^{\mathrm{c}}$ Reported as $H$. flaminius (probably H. hemipterinus)

${ }^{\mathrm{d}}$ Probably hyperparasitoid

parasitize several species of Coccinellini but has not been reported to attack $H$. axyridis.

As typical of idiobiont parasitoids, Phalacrotophora species are relatively polyphagous. A broad host range has been reported for European species, $P$. fasciata and $P$. berolinensis, and to a lesser extent for $P$. delageae, and for a South American species, $P$. nedae. Possibly, $P$. nedae can also parasitize $H$. 
axyridis, as it has been reported from other ladybirds in the same tribe (Coccinellini: Cycloneda, Neda, Neocalvia) (Ceryngier et al. 2012).

According to Filatova (1974) and Kuznetsov (1987), rates of parasitism of $H$. axyridis by $P$. fasciata in Asia did not differ considerably from the average rate for other ladybird hosts. In Europe, however, $H$. axyridis tends to be less affected by the species of Phalacrotophora than native ladybirds (Steenberg and Harding 2010; Ware et al. 2010; Comont et al. 2014). Furthermore, Ware et al. (2010) indicate that in the early phase of colonization of a new area $H$. axyridis might be either not parasitized or parasitized less compared to several years after arrival (Table 3).

To test the significance of these trends, we analyzed the data from Table 3 using binomial Generalized Linear Model (GLM) and Generalized Linear Mixed Model (GLMM). For comparisons between $H$. axyridis and other species, the study was used as random effect (see San Martin (2017) for the R code and detailed analysis output). However, as sample sizes were not mentioned in most data from the $H$. axyridis native range (Filatova 1974; Kuznetsov 1987), we imputed the missing sample sizes to conservative values of $\mathrm{N}=50$. The difference in the level of parasitism of $H$. axyridis and other species is well expressed in the invaded regions but not in the native range (highly significant Species x Region interaction in a binomial GLMM, fixed effect $=-2.8286$, $\mathrm{z}=-3.802, p=0.0001)$. In the native range of $H$. axyridis, the average parasitism rate of $H$. axyridis $($ GLMM estimate $=16.2 \%)$ was very similar to that of the other species combined (15.19\%), while in Europe the parasitism rate of $H$. axyridis was much lower $(0.76 \%)$ than the rate for other species $(10.76 \%)$ (Fig. 2a). There was a significantly lower parasitism rate of $H$. axyridis in Europe than in the native range (quasibinomial GLM, $\mathrm{F}_{1}, 15=19.68, p=0.0005$, Fig. 2b). A weak trend toward an increase of the parasitism rate with time in the European $H$. axyridis was also observed (slope in a quasibinomial $\mathrm{GLM}=0.2998, \mathrm{t}=2.308, p=0.038)($ Fig. $2 \mathrm{c}-\mathrm{d}$ ).

\section{Tachinidae (Diptera)}

Several tachinid flies attack coccinellids, mostly the juvenile stages of phytophagous species in the tribe Epilachnini (Ceryngier et al. 2012). However, two genera, Medina and Strongygaster, parasitize
Coccinellini adults, including $H$. axyridis (Ceryngier and Hodek 1996; Ceryngier et al. 2012; Togni et al. 2015). All reports of Medina parasitizing ladybirds are from the Palaearctic region, both within and outside of the native range of $H$. axyridis (Ceryngier and Hodek 1996). In the Chuncheon area in Korea, Park et al. (1996) recorded parasitism rates of $H$. axyridis by Medina sp. between 0.7 and $21.1 \%$. In the Primorye region of the Russian Far East, Kuznetsov (1975) noted between 3.7 and $4.3 \%$ parasitism of $H$. axyridis. Outside of the native range, $H$. axyridis has been parasitized by M. separata (Meigen) in Britain (Roy et al. 2016). Moreover, tachinid larvae (probably of the genus Medina) were found in dissected adults of $H$. axyridis collected from overwintering sites in the vicinity of Warsaw (Poland) during February-April 2015. The recorded prevalence was low $(0.48 \%$, $n=835$ ) and most of the tachinid larvae (3 of 4 ) were found dead and melanized (P. Ceryngier, unpublished data). In the Danish monitoring of natural enemies of ladybirds, tachinid larvae have not yet been recorded from $H$. axyridis $(n=2299)$, while they were found in very low prevalences in C. septempunctata $(0.21 \%, n=483)$ and A. bipunctata $(0.31 \%$, $n=635)$ (T. Steenberg, unpublished data).

Members of the genus Strongygaster are parasitoids of ladybirds in the Western Hemisphere. The North American S. triangulifera (Loew) is a polyphagous parasitoid of insects from several orders (Coleoptera, Lepidoptera, and Heteroptera) (Arnaud 1978; Golec et al. 2013). Nalepa et al. (1996), Katsoyannos and Aliniazee (1998) and Nalepa and Kidd (2002) found $S$. triangulifera attacking $H$. axyridis in the United States (North Carolina, Virginia, and Oregon). Parasitism rates ascertained by dissections of hosts fluctuated among years and localities from 0 to $31 \%$. Rearing $H$. axyridis from a sample collected in Oregon yielded in emergence of the flies from $4.8 \%$ of the beetles, while the parasitism rate in the dissected subsample was $15.4 \%$ (Katsoyannos and Aliniazee 1998). Recently, another species of Strongygaster, $S$. brasiliensis (Townsend) was discovered parasitizing H. axyridis in Brazil (Togni et al. 2015).

\section{Dinocampus coccinellae (Schrank) (Hymenoptera: Braconidae)}

Dinocampus coccinellae is a species of nearly cosmopolitan distribution. It is a solitary endoparasitoid 
Table 3 Rates of parasitism (and sample sizes if mentioned) by Phalacrotophora spp. of Harmonia axyridis (highlighted in bold) and other ladybird species at various localities within $H$. axyridis native and invasive ranges

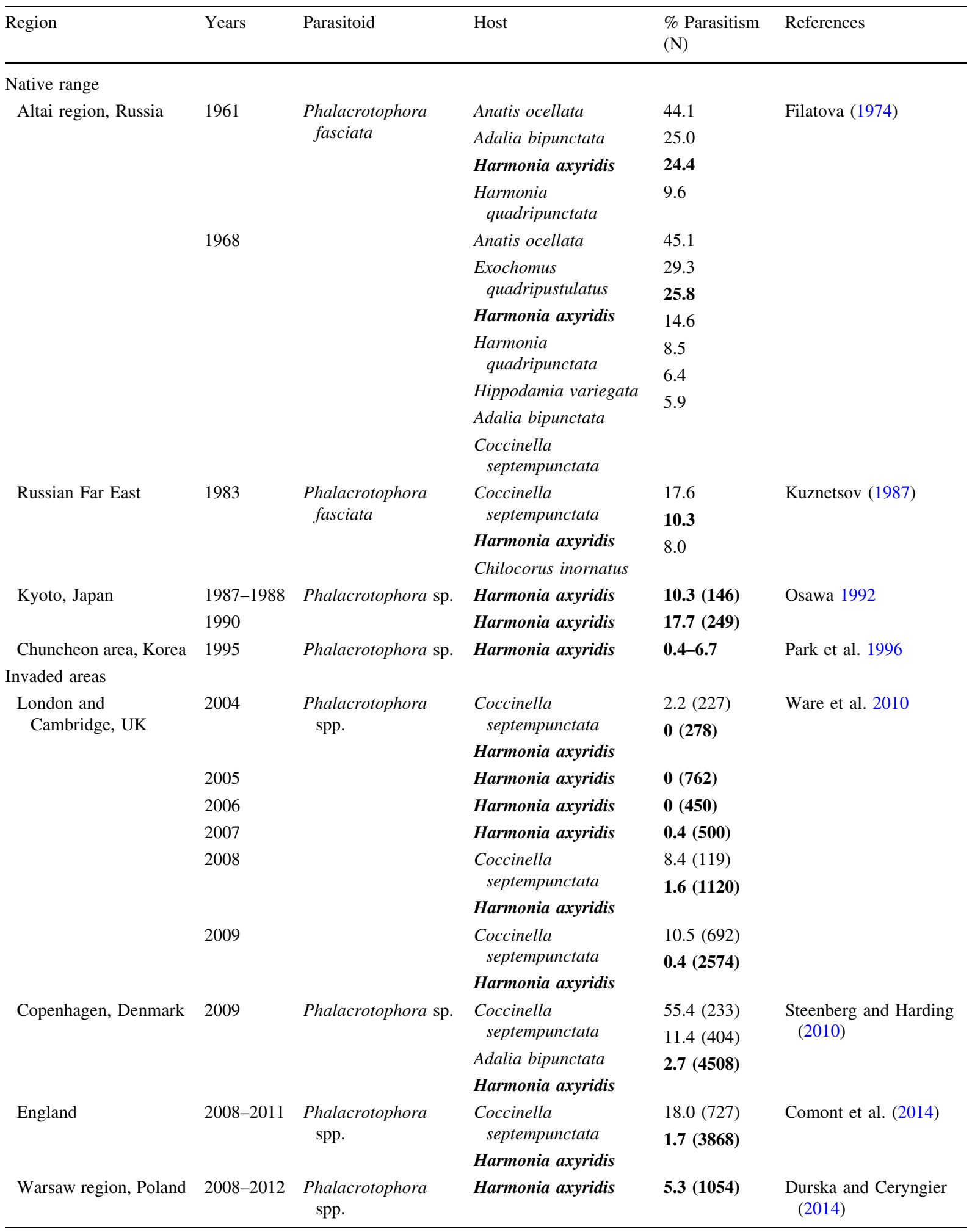


Table 3 continued

\begin{tabular}{|c|c|c|c|c|c|}
\hline Region & Years & Parasitoid & Host & $\begin{array}{l}\% \text { Parasitism } \\
\text { (N) }\end{array}$ & References \\
\hline \multirow[t]{2}{*}{ Bologna area, Italy } & 2013 & $\begin{array}{l}\text { Phalacrotophora } \\
\text { fasciata }\end{array}$ & Harmonia axyridis & $>5.1(98)^{\mathrm{a}}$ & Francati (2015) \\
\hline & 2014 & & Harmonia axyridis & $>0.8(125)^{a}$ & \\
\hline
\end{tabular}

Parasitism rates for species other than $H$. axyridis are only given in cases those species were sampled at the same period and region as H. axyridis

${ }^{\mathrm{a}}$ samples containing larvae and pupae (larvae are not parasitized by Phalacrotophora)
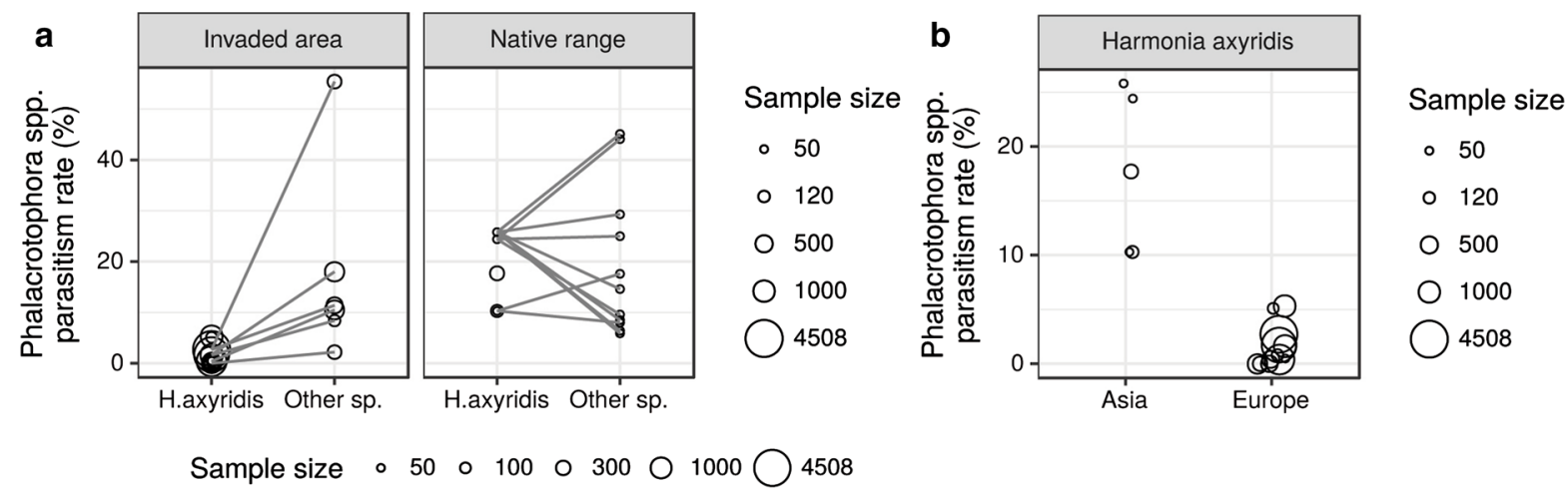
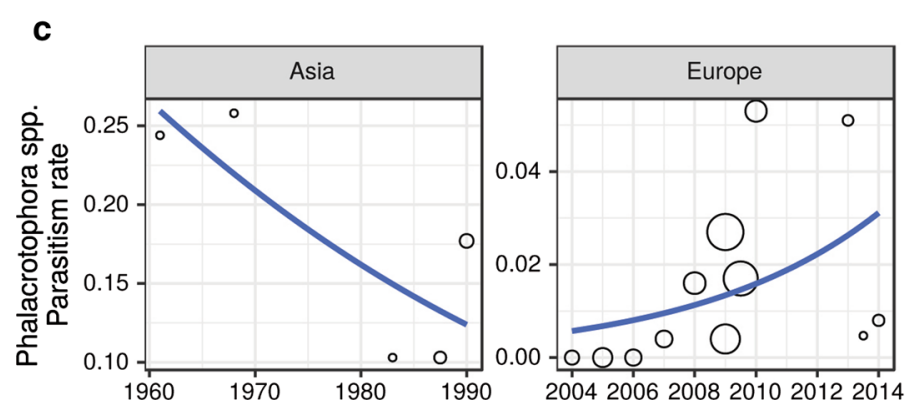

d

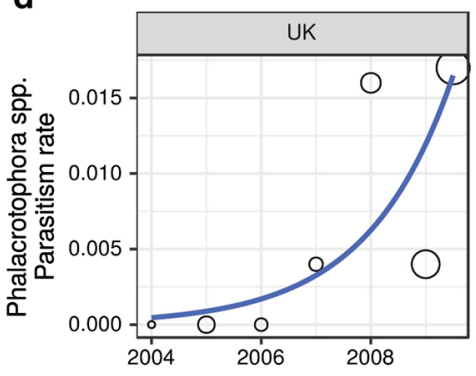

Sample size

- 278

○ 500

2000

3868
Fig. 2 Visualisation of the meta-analysis for parasitism by Phalacrotophora spp. a Parasitism rate of $H$. axyridis by Phalacrotophora spp. compared to all other ladybird species confounded. Lines connect observations from the same study and the same year. The level of parasitism of $H$. axyridis is significantly lower in the invaded areas, while in the native range it is similar to other host species. b Parasitism rate of $H$. axyridis in Europe compared to the native range There is a significantly lower rate in Europe. c Parasitism of H. axyridis

of many ladybird beetles, mostly in the tribe Coccinellini (54 host species reported) and much less frequently in Chilocorini (5 host species reported) (Ceryngier et al. 2012; Minnaar et al. 2014; Grez and Zaviezo unpubl. in Table 4). over time in the native range and in Europe. While the slope is negative in the native range (Asia), it was estimated with high imprecision; hence, the slope is not significantly different from 0 . In Europe, there is a positive trend, which is significantly different from 0 . d The UK is the only country with several years of data for parasitism of $H$. axyridis by Phalacrotophora (Ware et al. 2010; Comont et al. 2014). However, despite the strongly positive slope, it is not significantly different from 0 . See San Martin (2017) for details

Harmonia axyridis is a host of $D$. coccinellae (Fig. 3), with reports both within its native range and in all invaded continents (Table 2), but parasitism and emergence rates are usually low in comparison with other host species (Maeta 1969b; Hoogendoorn and 
Table 4 Rates of parasitism of Harmonia axyridis and other ladybirds by Dinocampus coccinellae and rates of emergence of $D$. coccinellae from the hosts at various localities in the native and invasive ranges of $H$. axyridis (sample sizes in brackets)

\begin{tabular}{|c|c|c|c|c|c|}
\hline Region & Years & Host & $\begin{array}{l}\% \text { Parasitism } \\
(\mathrm{N})\end{array}$ & $\begin{array}{l}\% \text { Emergence } \\
(\mathrm{N})\end{array}$ & References \\
\hline \multicolumn{6}{|l|}{ Native range } \\
\hline \multirow[t]{2}{*}{ Kurume, Japan } & 1960 & $\begin{array}{l}\text { Coccinella } \\
\text { septempunctata } \\
\text { brucki }\end{array}$ & $15.8(265)^{\mathrm{a}}$ & - & Maeta (1969b) \\
\hline & & $\begin{array}{l}\text { Harmonia } \\
\text { axyridis }\end{array}$ & $7.5(129)^{\mathrm{a}}$ & - & \\
\hline Ina, Japan & 1961 & $\begin{array}{l}\text { Harmonia } \\
\text { axyridis }\end{array}$ & $1.2(164)$ & - & \\
\hline \multicolumn{6}{|l|}{ Invaded areas } \\
\hline Oregon, USA & 1993-1994 & $\begin{array}{l}\text { Harmonia } \\
\text { axyridis }\end{array}$ & - & $<1(>2000)$ & LaMana and Miller (1996) \\
\hline Oregon, USA & 1997 & $\begin{array}{c}\text { Harmonia } \\
\text { axyridis }\end{array}$ & $1(101)$ & $0(42)$ & Katsoyannos and Aliniazee (1998) \\
\hline \multirow[t]{4}{*}{$\begin{array}{l}\text { Minnesota, } \\
\text { USA }\end{array}$} & 1999 & $\begin{array}{l}\text { Harmonia } \\
\text { axyridis }\end{array}$ & $23.8(63)$ & - & Hoogendoorn and Heimpel (2002) \\
\hline & & $\begin{array}{l}\text { Coleomegilla } \\
\text { maculata }\end{array}$ & $18.2(435)$ & - & \\
\hline & & $\begin{array}{l}\text { Coleomegilla } \\
\text { maculata }\end{array}$ & $14.5(110)$ & $10.5(57)$ & \\
\hline & 2000 & $\begin{array}{c}\text { Harmonia } \\
\text { axyridis }\end{array}$ & $8.9(282)$ & $1.2(84)$ & \\
\hline \multirow[t]{2}{*}{$\begin{array}{l}\text { Quebec, } \\
\text { Canada }\end{array}$} & 2002 & $\begin{array}{l}\text { Coleomegilla } \\
\text { maculata }\end{array}$ & $32.1(521)$ & $5.9(472)$ & Firlej et al. (2005) \\
\hline & & $\begin{array}{l}\text { Harmonia } \\
\text { axyridis }\end{array}$ & $4.6(453)$ & 0 (489) & \\
\hline \multirow[t]{2}{*}{ London, UK } & 2007 & $\begin{array}{l}\text { Coccinella } \\
\text { septempunctata }\end{array}$ & $10.0(110)$ & 11.9 (219) & Koyama and Majerus (2008) \\
\hline & & $\begin{array}{l}\text { Harmonia } \\
\text { axyridis }\end{array}$ & $7.6(237)$ & $0.2(474)$ & \\
\hline \multirow[t]{2}{*}{ UK } & 2008 & $\begin{array}{c}\text { Harmonia } \\
\text { axyridis }\end{array}$ & - & $0.8(1120)^{\mathrm{a}}$ & Hall et al. 2009 \\
\hline & & $\begin{array}{l}\text { Coccinella } \\
\text { septempunctata }\end{array}$ & - & $0(119)^{\mathrm{a}}$ & \\
\hline UK & 2011-2012 & $\begin{array}{l}\text { Harmonia } \\
\text { axyridis }\end{array}$ & - & $4-5^{\mathrm{a}}$ & $\begin{array}{l}\text { R. F. Comont (pers. comm.) in Raak-van } \\
\text { den Berg et al. } 2014 \text { (supplementary } \\
\text { material) }\end{array}$ \\
\hline Germany & 2008-2009 & $\begin{array}{l}\text { Harmonia } \\
\text { axyridis }\end{array}$ & 1 (1085) & 0 (1085) & Herz and Kleespies (2012) \\
\hline \multirow[t]{3}{*}{ The Netherlands } & 2004-2008 & $\begin{array}{l}\text { Harmonia } \\
\text { axyridis }\end{array}$ & 0 (1049) & - & Raak-van den Berg et al. (2014) \\
\hline & 2009 & $\begin{array}{l}\text { Harmonia } \\
\text { axyridis }\end{array}$ & $0.2(633)$ & $0(18,952)$ & \\
\hline & 2010 & $\begin{array}{l}\text { Harmonia } \\
\text { axyridis }\end{array}$ & $0.1(1652)$ & $<0.1(1453)$ & \\
\hline \multirow[t]{2}{*}{$\begin{array}{l}\text { Copenhagen, } \\
\text { Denmark }\end{array}$} & 2010 & $\begin{array}{l}\text { Coccinella } \\
\text { septempunctata }\end{array}$ & $28.6(14)$ & - & Steenberg, unpubl. \\
\hline & & $\begin{array}{l}\text { Harmonia } \\
\text { axyridis }\end{array}$ & $27.4(339)$ & - & \\
\hline
\end{tabular}


Table 4 continued

\begin{tabular}{|c|c|c|c|c|c|}
\hline Region & Years & Host & $\begin{array}{l}\% \text { Parasitism } \\
\text { (N) }\end{array}$ & $\begin{array}{l}\% \text { Emergence } \\
(\mathrm{N})\end{array}$ & References \\
\hline \multirow{6}{*}{$\begin{array}{l}\text { Bologna area, } \\
\text { Italy }\end{array}$} & \multirow[t]{2}{*}{2014} & $\begin{array}{l}\text { Coccinella } \\
\text { septempunctata }\end{array}$ & $4.4(45)$ & - & \\
\hline & & $\begin{array}{c}\text { Harmonia } \\
\text { axyridis }\end{array}$ & $3.5(172)$ & - & \\
\hline & \multirow[t]{4}{*}{2010} & $\begin{array}{l}\text { Coccinella } \\
\text { septempunctata }\end{array}$ & - & $6.2(113)$ & Dindo et al. (2016) \\
\hline & & $\begin{array}{l}\text { Harmonia } \\
\text { axyridis }\end{array}$ & - & $3.9(1348)$ & \\
\hline & & $\begin{array}{c}\text { Hippodamia } \\
\text { variegata }\end{array}$ & - & $2.4(40)$ & \\
\hline & & Adalia bipunctata & - & $2.3(43)$ & \\
\hline \multirow[t]{2}{*}{$\begin{array}{l}\text { Bologna area, } \\
\text { Italy }\end{array}$} & 2013 & $\begin{array}{l}\text { Harmonia } \\
\text { axyridis }\end{array}$ & - & $4.1(98)^{\mathrm{a}}$ & Francati $(2015$ \\
\hline & 2014 & $\begin{array}{c}\text { Harmonia } \\
\text { axyridis }\end{array}$ & - & $19.2(125)^{\mathrm{a}}$ & \\
\hline \multirow{5}{*}{$\begin{array}{l}\text { West Cape } \\
\text { Province, South } \\
\text { Africa }\end{array}$} & \multirow[t]{5}{*}{2013} & $\begin{array}{l}\text { Adalia } \\
\quad \text { flavomaculata }\end{array}$ & - & $11(37)$ & \multirow[t]{5}{*}{ Minnaar et al. (2014) } \\
\hline & & $\begin{array}{c}\text { Hippodamia } \\
\text { variegata }\end{array}$ & - & $9(78)$ & \\
\hline & & $\begin{array}{l}\text { Cheilomenes } \\
\quad \text { lunata }\end{array}$ & - & $4(68)$ & \\
\hline & & $\begin{array}{l}\text { Exochomus } \\
\text { flavipes }\end{array}$ & - & $3(35)$ & \\
\hline & & $\begin{array}{c}\text { Harmonia } \\
\text { axyridis }\end{array}$ & - & $1(276)$ & \\
\hline \multirow[t]{6}{*}{ Santiago, Chile } & \multirow[t]{6}{*}{2016} & Eriopis chilensis & $29.2(24)^{\mathrm{b}}$ & - & \multirow[t]{6}{*}{ Grez and Zaviezo. unpubl. } \\
\hline & & $\begin{array}{c}\text { Hippodamia } \\
\text { variegata }\end{array}$ & $46.4(28)^{\mathrm{b}}$ & - & \\
\hline & & $\begin{array}{c}\text { Harmonia } \\
\text { axyridis }\end{array}$ & $10.8(37)^{\mathrm{b}}$ & - & \\
\hline & & Eriopis chilensis & - & $16.6(253)^{\mathrm{c}}$ & \\
\hline & & $\begin{array}{c}\text { Hippodamia } \\
\text { variegata }\end{array}$ & - & $14.6(280)^{\mathrm{c}}$ & \\
\hline & & $\begin{array}{c}\text { Harmonia } \\
\text { axyridis }\end{array}$ & - & $4.7(43)^{\mathrm{c}}$ & \\
\hline \multirow{2}{*}{$\begin{array}{l}\text { České } \\
\text { Budějovice, } \\
\text { Czech Republic }\end{array}$} & 2015 & $\begin{array}{c}\text { Harmonia } \\
\text { axyridis }\end{array}$ & - & $0.4(280)$ & \multirow[t]{2}{*}{ Nedvěd, unpubl. } \\
\hline & 2016 & $\begin{array}{c}\text { Harmonia } \\
\text { axyridis }\end{array}$ & - & $26.1(46)$ & \\
\hline
\end{tabular}

Parasitism rate determined by dissection of field collected ladybirds, emergence rate-by rearing field collected ladybirds. Data for species other than $H$. axyridis are only given in cases those species were sampled at the same period and region as $H$. axyridis, data for $H$. axyridis are highlighted in bold

${ }^{a}$ From hosts collected as larvae or pupae

${ }^{\mathrm{b}}$ Adults collected in alfalfa in autumn (March-May)

${ }^{\mathrm{c}}$ Adults collected in alfalfa in spring (August-December) 
Heimpel 2002; Firlej et al. 2005, 2007, 2010; Koyama and Majerus 2008; Ceryngier et al. 2012; Minnaar et al. 2014; Table 4). Koyama and Majerus (2008) demonstrated that $D$. coccinellae of Japanese origin developed in British $H$. axyridis more successfully (about $17 \%$ successful parasitism rate) compared to wasps of British origin (no successful parasitism). On the other hand, about $25 \%$ of the Japanese as well as British wasps successfully developed in $H$. axyridis from Japan, suggesting that non-invasive ecotypes of $H$. axyridis may be more susceptible to various strains or geographic races of $D$. coccinellae than the invasive ecotype. However, some recent sequential data suggest that $D$. coccinellae may become better adapted to

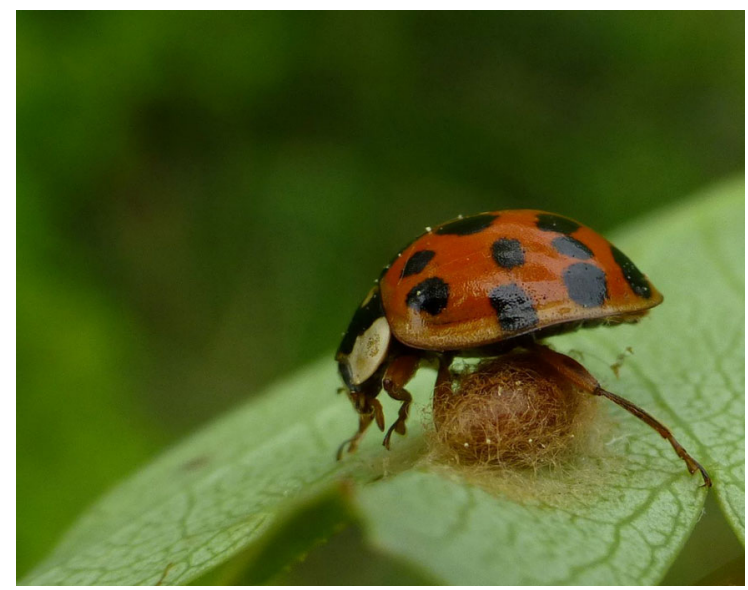

Fig. 3 Harmonia axyridis with a cocoon of its parasitoid Dinocampus coccinellae (photographed by Jean-Yves Baugnée) the invasive populations of $H$. axyridis (see data of Francati (2015) and Nedvěd, unpubl. in Table 4).

Dindo et al. (2016) found no significant differences in the rates of emergence of $D$. coccinellae from $H$. axyridis and three native ladybird species (C. septempunctata, Adalia bipunctata and Hippodamia variegata (Goeze)) in Italy. However, the samples of the two species with low suitability for $D$. coccinellae (A. bipunctata and $H$. variegata) were very small. Our GLMM analysis of the data from Table 4 reveals a significantly lower parasitism rate (fixed effect $=1.1099, \mathrm{z}=2.439, p=0.015$ ) of $H$. axyridis in its invaded areas compared to the other species pooled (Fig. 4a). The same is true for the emergence rate (fixed effect $=1.8531, \mathrm{z}=3.334, p=0.0009$ ) (Fig. 4b). The data from the native range are too scarce to be used. Furthermore, we did not observe any temporal trend in the parasitism and emergence rates in this dataset.

\section{Tetrastichinae (Hymenoptera: Eulophidae)}

Of several species in this subfamily that are known as ladybird parasitoids, the most frequently reported is Oomyzus scaposus (Thomson). This widely distributed minute wasp is a larval-pupal endoparasitoid of many ladybird species, mostly in the tribes Coccinellini and Chilocorini (Ceryngier et al. 2012). It parasitizes $H$. axyridis in its native range in Western Siberia (Filatova 1974) and the Russian Far East (Kuznetsov 1987, 1997) as well as in the invasive

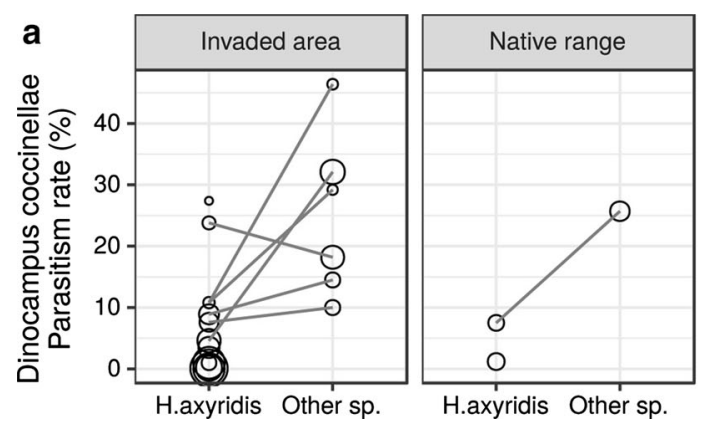

Fig. 4 Visualisation of the meta-analysis for parasitism by and emergence of Dinocampus coccinellae. a Parasitism rate of $H$. axyridis by $D$. coccinellae relative to all other ladybird species confounded. Lines connect observations from the same study and the same year. The level of parasitism of $H$. axyridis is significantly lower than of other host species. When considering the invaded areas only, the lower parasitism of $H$. axyridis is

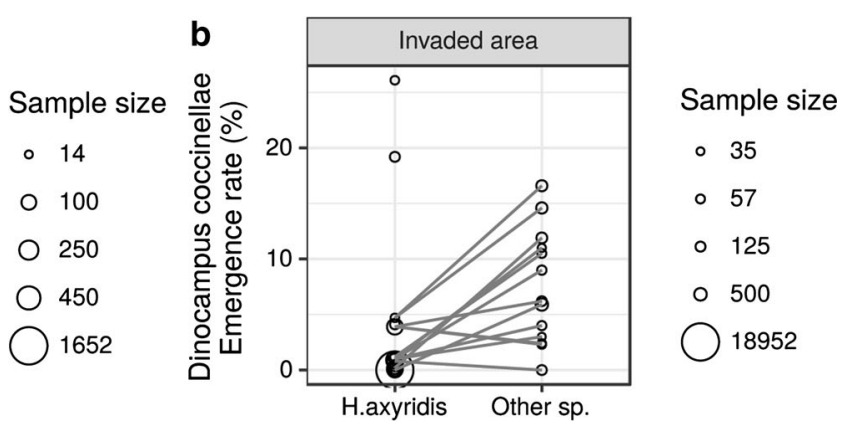

close to significant. b Emergence rate of $D$. coccinellae from $H$. axyridis relative to all other ladybird species confounded. No data are available for emergence rate from the native range. Again, the rate of emergence of $D$. coccinellae when using $H$. axyridis as a host is significantly lower compared to other host species. See San Martin (2017) for details 
areas in North America (Riddick et al. 2009) and Britain (Ware et al. 2010; Comont et al. 2014). Riddick et al. (2009) reported that $44 \%$ of $48 \mathrm{H}$. axyridis pupae collected in North Carolina (USA) were parasitized by $O$. scaposus. In the same sample, also another species of Tetrastichinae, Aprostocetus neglectus (Domenichini), was recorded. Ware et al. (2010) found $O$. scaposus as an occasional parasitoid of $H$. axyridis in Britain; between 2004 and 2008 no parasitism by this species was recorded, while in 2009 , two of $2574 \mathrm{H}$. axyridis pupae $(0.08 \%)$ were parasitized. In Denmark $O$. scaposus occasionally parasitizes C. septempunctata $(1.3 \%, n=397)$ and $A$. bipunctata $(0.5 \%, n=730)$, but it has not been recorded in pupae of $H$. axyridis (11,394 pupae examined between 2007 and 2016) (Steenberg and Harding, unpublished data).

\section{Homalotylus spp. (Hymenoptera: Encyrtidae)}

Wasps of the genus Homalotylus are endoparasitoids of ladybird larvae and pupae. Approximately 30 of 67 described species parasitize Coccinellidae, and the remaining species are also thought to parasitize ladybirds as well (Ceryngier et al. 2012; Noyes 2017). The taxonomy of the Homalotylus species most frequently reported from the hosts in the tribe Coccinellini, including $H$. axyridis, has often been confused during the past 100 years. Usually it has erroneously been determined as H. flaminius (Dalman) (the species parasitizing ladybirds in the tribe Scymnini) and less frequently as $H$. eytelweinii (Ratzeburg) (described from Germany as a parasitoid of Anatis ocellata). Noyes (2010) and Trjapitzin (2013), however, suggest that the proper name of this species probably is $H$. hemipterinus (De Stefani). It was reported parasitizing $H$. axyridis in the Russian Far East (Kuznetsov 1997; Trjapitzin 2011), in Croatia (Glavendekić et al. 2010), and in Britain (Roy et al. 2016). In North Carolina (USA), H. axyridis was attacked by yet another species, H. terminalis (Say) (Riddick et al. 2009).

Potential of predators and parasitoids to limit $H$. axyridis numbers

Harmonia axyridis is protected chemically against predation and more so than many other coccinellids (Sloggett et al. 2011). Many laboratory assays indicate its higher toxicity and/or unpalatability compared to other members of aphidophagous guilds (ladybirds, lacewings) (Phoofolo and Obrycki 1998; Cottrell 2004; Sato and Dixon 2004; Kajita et al. 2010; Nedvĕd et al. 2010). Further protection of the larvae is provided by spiny projections on their cuticle. Apart from these chemical and mechanical defenses, $H$. axyridis is also equipped with a biological weapon against some predators-symbiotic microsporidia, which are lethal to potential intraguild predators, $C$. septempunctata and A. bipunctata (Vilcinskas et al. 2013, 2015; Vogel et al. 2017; but see Sloggett 2013; Solter et al. 2013; Gegner et al. 2015).

A broad repertoire of $H$. axyridis defenses combined with limited evidence of predation by vertebrate and invertebrate carnivores indicate that predators are unlikely to play a considerable role in reducing harlequin ladybird populations. Although some birds (Delichon urbica, Passer montanus) and invertebrates (Araneus diadematus, Steatoda nobilis, Podisus maculiventris, Chrysoperla carnea) do not avoid $H$. axyridis as a prey, their contribution to the control of the latter is probably not high.

The chemical and morphological defenses protecting $H$. axyridis against predators are probably less effective against parasitoids. Instead, the ladybird's immune responses to and physiological and nutritional unsuitability for the development of parasitoid eggs and larvae may represent the main defensive strategy. These questions were studied in detail by Firlej et al. (2007, 2012) using the H. axyridis-D. coccinellae system. They found that $H$. axyridis possesses an effective immune system that is able to destroy the parasitoid eggs through encapsulation by hemocytes (Firlej et al. 2012). If the egg is not destroyed and the larva hatches, its development may be impeded or delayed due to a reduced number and inappropriate growth pattern of teratocytes, cells originating from the serosa of the parasitoid egg that serve as food for the parasitoid larva (Firlej et al. 2007). It is also possible that the microsporidia discovered in $H$. axyridis (Vilcinskas et al. 2013) contribute to its low suitability for D. coccinellae. No empirical confirmation of this exists so far, but the finding of Sluss (1968) that the successful development of $D$. coccinellae was prevented in microsporidia-infected ladybirds (Hippodamia convergens Guérin) makes this hypothesis plausible. It should also be tested whether other pathogens and parasites of $H$. axyridis, especially the 
nematode Parasitylenchus bifurcatus Poinar and Steenberg (Harding et al. 2011; Poinar and Steenberg 2012; Haelewaters et al. 2017), can interfere with $D$. coccinellae larval development.

Another hypothesis that needs testing assumes that $H$. axyridis may be more resistant than other ladybirds to the $D$. coccinellae paralysis virus. This virus, after transmission from the parasitoid larva to the host ladybird nervous system, replicates in the cerebral ganglia causing paralysis of the ladybird. This enables the emerging larva to spin a cocoon between the host's legs and consequently gain protection beneath the aposematically coloured and chemically defended host body (Dheilly et al. 2015). The virus-induced paralysis is temporary and ladybirds can sometimes recover and even resume their reproductive activity (Triltsch 1996; Maure et al. 2014). If the intensity of paralysis is weak and/or its duration short, the role of parasitoid bodyguard played by the ladybird may be incomplete. It seems probable that $H$. axyridis often provides incomplete bodyguard protection to its $D$. coccinellae parasitoid. Quick resumption of walking and feeding ability of $H$. axyridis following $D$. coccinellae emergence was observed several times and in one case the emerged parasitoid was consumed by the host ladybird (P. Ceryngier, unpubl.).

Despite its low suitability for development of $D$. coccinellae, $H$. axyridis is no less preferred for oviposition by this wasp than more suitable hosts (Hoogendoorn and Heimpel 2002; Koyama and Majerus 2008; Firlej et al. 2010). Furthermore, interacting with $D$. coccinellae females, $H$. axyridis adults display more behavioural defenses than do the adults of suitable hosts, such as Coleomegilla maculata (DeGeer), which increases the handling time of the parasitoid and hence further reduces its fitness (Firlej et al. 2010). Finally, although $H$. axyridis larvae are more suitable for development of $D$. coccinellae than adults (Firlej et al. 2007, 2010; Berkvens et al. 2010), the latter are more readily parasitized by D. coccinellae (Firlej et al. 2010). In conclusion, $H$. axyridis populations within the invaded range seem unlikely to be reduced to a significant extent by $D$. coccinellae. Instead, $H$. axyridis may represent an ecological trap or at least a sink for $D$. coccinellae eggs (Hoogendoorn and Heimpel 2002; Firlej et al. 2010).

Physiological interactions between $H$. axyridis and parasitoids other than $D$. coccinellae have not been investigated yet, but it can be expected that these interactions might limit the developmental success of koinobiont parasitoids, such as $O$. scaposus and Homalotylus spp. Both occasionally attack $H$. axyridis larvae and pupae at low prevalences (but see Riddick et al. 2009), which may be attributed to either low oviposition rates or low successful parasitism. Idiobiont parasitoids, like flies of the genus Phalacrotophora, quickly kill their hosts and then develop in host corpses. Therefore, physiological host-parasitoid interactions, if established at all, will be weak and short-lasting. Perhaps due to this, the reported rates of parasitism of $H$. axyridis by Phalacrotophora spp. (especially in the native range of $H$. axyridis) are higher than those attained by the koinobionts. On the other hand, the branched spiny projections on $H$. axyridis larvae may hamper oviposition of females of Tetrastichinae and Homalotylus. This is not the case with Phalacrotophora females which oviposit (during ladybird ecdysis to the pupal stage) into smooth and soft pupal skin (Ceryngier et al. 2012). Of $H$. axyridis parasitoids in the Palaearctic region, Phalacrotophora flies might be the most important, although their role is still poorly known.

Enemy release hypothesis and enemy acquisition

Populations of a non-native species introduced in a new area may escape from its natural enemies as proposed by the enemy release hypothesis (ERH) but may also, often after a certain time lag, become prone to attacks from native predators, parasitoids, parasites, and pathogens. The latter process, when an association of a non-native species with a native enemy is established, is referred to as "enemy acquisition".

ERH can be considered at a biogeographical and community scale (Colautti et al. 2004). Biogeographical studies compare diversity and impact of natural enemies attacking a given species in its native and introduced ranges, while community studies compare diversity and impact of enemies of co-occurring native and non-native species. Below we briefly discuss these two approaches limiting our considerations to parasitoids. Too few data are available on $H$. axyridis predators and, on the other hand, it is not very likely that these principally generalist zoophages may be involved in the enemy release phenomenon.

At a biogeographical scale, no conclusive statements can be made as to whether the ERH is pertinent to $H$. axyridis invasion. The recorded richness of $H$. 
axyridis parasitoids in the native range (at least 6 species of primary parasitoids and one hyperparasitoid) is higher than in most of invaded continents (5 species of primary parasitoids plus 1 hyperparasitoid in North America, 2 species in South America, 1 species in Africa), but lower than in Europe (8 species) (Table 2). These figures, however, do not necessarily reflect the actual differences among regions, but may be related to the unequal state of knowledge on this topic in different geographic regions. Indeed, more studies on ladybird parasitoids have been conducted in Europe than in the remaining continents invaded by $H$. axyridis and the native area in Asia as well.

The most common parasitoids of ladybirds of the tribe Coccinellini in the Palaeactic region are hymenopterans D. coccinellae, $O$. scaposus, and $H$. hemipterinus, and dipterans of the genus Phalacrotophora. (Ceryngier et al. 2012). All of them have been reported to parasitize $H$. axyridis in its native range. Yet, the hymenopterans mentioned above also occur within the invasive ranges of $H$. axyridis, not only in the Palaearctic (Europe) but also in South America, North America (maybe with the exception of H. hemipterinus), and Africa (Noyes 2010, 2017; Ceryngier et al. 2012). As to species of Phalacrotophora parasitic in Coccinellini, they have been reported from the invasive ranges of $H$. axyridis in Europe and South America. Thus, according to the present knowledge on the distribution of $H$. axyridis parasitoids, the enemy release in the literal meaning only concerns escape of a few invasive populations of the harlequin ladybird from parasitism by a few parasitoids, e.g. escape of North American and African populations from parasitism by Phalacrotophora. When considering the enemy release not as a simple presence/absence opposition, but in terms of differences in the parasitism rates reached in the native and invaded areas, some support for the ERH can be found: rates of parasitism of $H$. axyridis by Phalacrotophora spp. tend to be higher in Asia than in Europe (Table 3).

Stronger support for the ERH is provided by the community approach. Comparing parasitism of the invasive $H$. axyridis with that of the native ladybirds, lower prevalences are usually recorded in the former. This applies to parasitism by both Phalacrotophora spp. (Table 3) and D. coccinellae (Table 4). While discussing applicability of the enemy release, however, the community studies should not be considered in isolation from the biogeography comparisons and research on the physiological, immunological or behavioural host-enemy interactions. It is well documented that $H$. axyridis belongs to hosts of low suitability for $D$. coccinellae not only in the areas outside of the ladybird native range, but also within this range (Maeta 1969b; Koyama and Majerus 2008; Ceryngier et al. 2012). Nonetheless, study by Koyama and Majerus (2008) suggests that $D$. coccinellae from the native area of $H$. axyridis may be better adapted to exploit it.

Although some evidence, both at the level of biogeography and community, indicates that the European populations of $H$. axyridis may have experienced partial release from parasitism by Phalacrotophora spp., the faunistic data point at enemy acquisition rather than enemy release. While two species of Phalacrotophora ( $P$. fasciata and $P$. philaxyridis) are known to affect the native populations of $H$. axyridis, four species (P. fasciata and three other species) have been recorded in Europe. Two of these three species other than $P$. fasciata $(P$. berolinensis and $P$. delageae) are not known to occur outside of Europe, and the third one ( $P$. beuki) is known from Europe and Israel (Ceryngier et al. 2012; Mostovski 2016). Interestingly, none of the native European ladybirds has been found to host so many Phalacrotophora parasitoids as the invasive $H$. axyridis. All four species of Phalacrotophora were found parasitizing $H$. axyridis in Warsaw and its surroundings (Poland) during the studies conducted between 2008 and 2012. From among 1054 collected pupae of $H$. axyridis, $56(5.3 \%)$ were parasitized by phorid flies, and of them the most common was $P$. delageae, followed by $P$. fasciata, $P$. berolinensis and $P$. beuki (Durska and Ceryngier 2014). The latter species was previously reported only from Anatis ocellata (Durska et al. 2003). That $H$. axyridis may be parasitized by a wider array of Phalacrotophora parasitoids than the native European species is also confirmed by studies conducted in Britain. Ware et al. (2010) and Comont et al. (2014) found $H$. axyridis parasitized by $P$. fasciata and $P$. berolinensis, while $C$. septempunctata only by $P$. fasciata.

Further examples of parasitoid acquisition by the invasive $H$. axyridis include flies of the genus Strongygaster (S. triangulifera and S. brasiliensis) and the wasp H. terminalis (Table 2). As those species 
are only known from the New World, $H$. axyridis almost certainly is their novel host.

Several parasitoids reported from $H$. axyridis are widely distributed in many parts of the world. This concerns $D$. coccinellae, $O$. scaposus, $H$. hemipterinus and to a lesser degree $P$. fasciata. Perhaps populations of these species from different regions have different requirements and host-use adaptations and hence should be regarded as distinct ecological entities. Studies by Koyama and Majerus (2008) showing differences between the Japanese and British $D$. coccinellae support this view. Such an approach, however, implies that $H$. axyridis invading a new area may escape from one geographic ecotype or race of a given parasitoid to acquire another one, often after a certain time lag.

To conclude this section, in the initial phase of $H$. axyridis invasion the enemy release has possibly contributed to the spread and increase of the invader's populations. Later, however, novel associations might start to establish mitigating previous effects of the enemy release. Acquisition of new enemies by $H$. axyridis in the invaded areas does not only apply to parasitoids. True parasites, such as the mite Coccipolipus hippodamiae (McDaniel and Morrill), the nematode Parasitylenchus bifurcatus, and the fungus Hesperomyces virescens Thaxter, are also believed to have been acquired by the populations of the harlequin ladybird in the invaded range (Ceryngier and Twardowska 2013; Haelewaters et al. 2016, 2017).

\section{Conclusions and perspectives}

There is little evidence of population limitation of $H$. axyridis by predators or parasitoids. Predatory vertebrates and invertebrates usually avoid preying on $H$. axyridis and those that accept it as a prey, being broad generalists, do this opportunistically. There may be more opportunities for such generalist predators to attack $H$. axyridis during population outbreaks. However, whether or not predators can provide any degree of control of $H$. axyridis during such events requires observational and experimental data.

Rates of parasitism of $H$. axyridis by the hymenopteran parasitoids (D. coccinellae, Homalotylus sp., Tetrastichinae) are generally low, both in the native and invaded areas of the ladybird. Possible reasons of this are (1) low rates of oviposition into H. axyridis by the parasitoid females, (2) low nutritional suitability of H. axyridis, and/or (3) its effective immune response. Physiological and immunological interactions may also play a role in lowering the successful parasitism of $H$. axyridis by the tachinid flies of the genera Medina and Strongygaster.

The most promising control agents of $H$. axyridis among parasitoids seem to be phorid flies of the genus Phalacrotophora (many species involved, relatively high parasitism rates-see Table 3). They are idiobiont parasitoids and hence can evade the effects of $H$. axyridis immune system. There are many species of Phalacrotophora parasitizing various species of Coccinellini ladybirds. Field studies to be conducted in different regions would clarify the host spectra of individual Phalacrotophora species and show which of them parasitize $H$. axyridis and to what extent. The host range, geographic distribution, and abundance of $P$. philaxyridis is especially worth checking. Currently, this species is only known as a parasitoid of $H$. axyridis with very scarce data coming from only one locality in Japan (Disney 1997).

Although the present state of knowledge indicates that the majority of ladybird parasitoids are unable to exert any significant effect on $H$. axyridis populations, it cannot be excluded that some of the parasitoids native to the areas invaded by the harlequin ladybird will adapt to exploit it more efficiently. Moreover, bearing in mind great potential of the invasive populations of $H$. axyridis for long-distance translocations (Lombaert et al. 2010; Brown et al. 2011), it is also possible that some of the parasitoids may disperse with the hosts to other regions (co-colonization of new areas). This may especially be the case with imaginal parasitoids, such as D. coccinellae. For examining geographic variation of $H$. axyridis parasitoids and their possible host-driven spreading, large-scale genetic comparisons are required.

Acknowledgements We thank Omar Cerna, Fernando Téllez, and Renato Vítek for sharing their unpublished observations. We are grateful to two anonymous referees for their very useful comments and suggestions. AG and TZ were supported by FONDECYT 1140662 (Chile). HER received support from the Natural Environment Research Council (via National Capability funding to the Centre for Ecology and Hydrology, project NEC04932) and is grateful to the COST Action TD1209 ALIEN Challenge for opportunities to network and exchange information. 


\section{Compliance with ethical standards}

Conflict of interest The authors declare that they have no conflict of interests.

Open Access This article is distributed under the terms of the Creative Commons Attribution 4.0 International License (http:// creativecommons.org/licenses/by/4.0/), which permits unrestricted use, distribution, and reproduction in any medium, provided you give appropriate credit to the original author(s) and the source, provide a link to the Creative Commons license, and indicate if changes were made.

\section{References}

Arnaud PH Jr (1978) A host-parasite catalog of North American Tachinidae (Diptera). USDA Misc Publ 1319:1-860

Berkvens N, Bonte J, Berkvens D, Deforce K, Tirry L, De Clercq P (2008) Pollen as an alternative food for Harmonia axyridis. Biocontrol 53:201-210

Berkvens N, Moens J, Berkvens D, Samih MA, Tirry L, De Clercq P (2010) Dinocampus coccinellae as a parasitoid of the invasive ladybird Harmonia axyridis in Europe. Biol Control 53:92-99

Bozsik A (2016) Hogyan védekezhetünk az ázsiai katicabogár Harmonia axyridis (Pallas, 1973) ellen. In: Horváth J, Haltrich A, Molnár J (eds) Növényvédelmi Tudományos Napok 2016, Budapest, 2016. Február 16-17, p 34

Brown PMJ, Thomas CE, Lombaert E, Jeffries DL, Estoup A, Lawson Handley L-J (2011) The global spread of Harmonia axyridis (Coleoptera: Coccinellidae): distribution, dispersal and routes of invasion. Biocontrol 56:623-641

Bukejs A, Telnov D (2015) The first record of the invasive lady beetle Harmonia axyridis (Pallas, 1773) (Coleoptera: Coccinellidae) in Turkey. Zool Ecol 25:59-62

Burgio G, Lanzoni A, Accinelli G, Maini S (2008) Estimation of mortality by entomophages on exotic Harmonia axyridis versus native Adalia bipunctata in semi-field conditions in northern Italy. Biocontrol 53:277-287

Camacho-Cervantes M, Ortega-Iturriaga A, del-Val E (2017) From effective biocontrol agent to successful invader: the harlequin ladybird (Harmonia axyridis) as an example of good ideas that could go wrong. PeerJ 5:e3296. https://doi. org/10.7717/peerj.3296

Ceryngier P, Hodek I (1996) Enemies of Coccinellidae. In: Hodek I, Honĕk A (eds) Ecology of Coccinellidae. Kluwer, Dordrecht, pp 319-350

Ceryngier P, Twardowska K (2013) Harmonia axyridis (Coleoptera: Coccinellidae) as a host of the parasitic fungus Hesperomyces virescens (Ascomycota: Laboulbeniales, Laboulbeniaceae): a case report and short review. Eur J Entomol 110:549-557

Ceryngier P, Roy HE, Poland RL (2012) Natural enemies of ladybird beetles. In: Hodek I, van Emden HF, Honek A (eds) Ecology and behaviour of the ladybird beetles (Coccinellidae). Wiley-Blackwell, Chichester, pp 375-443

Colautti RI, Ricciardi A, Grigorovich IA, MacIsaac HJ (2004) Is invasion success explained by the enemy release hypothesis? Ecol Lett 7:721-733
Comont RF, Purse BV, Phillips W, Kunin WE, Hanson M, Lewis OT, Harrington R, Shortall CR, Rondoni G, Roy HE (2014) Escape from parasitism by the invasive alien ladybird, Harmonia axyridis. Insect Conserv Diver 7:334-342

Cottrell TE (2004) Suitability of exotic and native lady beetle eggs (Coleoptera: Coccinellidae) for development of lady beetle larvae. Biol Control 31:362-371

Daloze D, Braekman J-C, Pasteels JM (1995) Ladybird defence alkaloids: structural, chemotaxonomic and biosynthetic aspects (Col.: Coccinellidae). Chemoecology 5(6): 173-183

De Clercq P, Peeters I, Vergauwe G, Thas O (2003) Interaction between Podisus maculiventris and Harmonia axyridis, two predators used in augmentative biological control in greenhouse crops. Biocontrol 48:39-55

Dheilly NM, Maure F, Ravallec M, Galinier R, Doyon J, Duval D, Leger L, Volkoff A-N, Missé D, Nidelet S, Demolombe V, Brodeur J, Gourbal B, Thomas F, Mitta G (2015) Who is the puppet master? Replication of a parasitic wasp-associated virus correlates with host behaviour manipulation. Proc R Soc B 282:20142773

Dindo ML, Francati S, Lanzoni A, di Vitantonio C, Marchetti E, Burgio G, Maini S (2016) Interactions between the multicolored Asian lady beetle Harmonia axyridis and the parasitoid Dinocampus coccinellae. Insects 7:67

Disney RHL (1997) A new species of Phoridae (Diptera) that parasitises a widespread Asian ladybird beetle (Coleoptera: Coccinellidae). The Entomologist 116:163-168

Disney RHL (2012) Five new species of scuttle fly (Diptera: Phoridae) from southern Africa. Afr Invertebr 53:113-124

Disney RHL, Chazeau J (1990) The recognition and biology of Phalacrotophora quadrimaculata (Diptera: Phoridae) parasitising Olla v-nigrum (Coleoptera: Coccinellidae) used in attempts to control the Leucaena psyllid. Ann Parasitol Hum Comp 65:98-100

Dolenská M, Nedvěd O, Veselý P, Tesařová M, Fuchs R (2009) What constitutes optical warning signals of ladybirds (Coleoptera: Coccinellidae) towards bird predators: colour, pattern or general look? Biol J Linn Soc 98:234-242

Drumont A (2011) Nouvelle donnée pour Dinocampus coccinellae (Schrank) (Hymenoptera, Braconidae) en tant que parasitoïde d'Harmonia axyridis (Pallas) (Coleoptera, Coccinellidae). Bull SRBE KBVE 147:109-112

Durska E, Ceryngier P (2014) Parasitization of the invasive ladybird, Harmonia axyridis, by native phorid parasitoids in Poland. In: Dorchin N, Kotrba M, Mengual X, Menzel F (eds) 8th international congress of dipterology, Potsdam 2014, Abstract volume, p 88

Durska E, Ceryngier P, Disney RHL (2003) Phalacrotophora beuki (Diptera: Phoridae), a parasitoid of ladybird pupae (Coleoptera: Coccinellidae). Eur J Entomol 100:627-630

Faúndez EI (2015) La chinche asesina Zelus renardii (Kolenati, 1856) (Heteroptera: Reduviidae) en Chile: Comentarios después de 15 años de su llegada al país. Boletín de la Sociedad Entomológica Aragonesa (S.E.A.) 57:421-423

Filatova IT (1974) The parasites of Coccinellidae (Coleoptera) in West Siberia. In: Kolomyietz NG (ed) The fauna and ecology of insects from Siberia. Publ. House "Nauka", Siberian Branch, Novosibirsk, pp 173-185 in Russian 
Firlej A, Boivin G, Lucas É, Coderre D (2005) First report of Harmonia axyridis Pallas being attacked by Dinocampus coccinellae Schrank in Canada. Biol Invasions 7:553-556

Firlej A, Lucas É, Coderre D, Boivin G (2007) Teratocytes growth pattern reflects host suitability in a host-parasitoid assemblage. Physiol Entomol 32:181-187

Firlej A, Lucas É, Coderre D, Boivin G (2010) Impact of host behavioral defenses on parasitization efficacy of a larval and adult parasitoid. Biocontrol 55:339-348

Firlej A, Girard P-A, Brehélin M, Coderre D, Boivin G (2012) Immune response of Harmonia axyridis (Coleoptera: Coccinellidae) supports the enemy release hypothesis in North America. Ann Entomol Soc Am 105:328-338

Francati S (2015) Native preimaginal parasitism of Harmonia axyridis: new record of association with Phalacrotophora fasciata in Italy. Bull Insectol 68:3-6

Fremlin M (2007) Intra-guild predation of harlequin ladybird larvae by lacewing larvae. Bull Amat Entomol Soc 66:110-116

Gegner T, Otti O, Tragust S, Feldhaar H (2015) Do microsporidia function as "biological weapon" for Harmonia axyridis under natural conditions? Insect Sci 22:353-359

Glavendekić M, Mihajlović L, Hrašovec B (2010) Native species Homalotylus flaminius Dalman (Hymenoptera, Encyrtidae) parasitoid of Harmonia axyridis on Balkan Peninsula. In: Population dynamics, biological control, and integrated management of forest insects, 12-16 September 2010, Eberswalde, Germany, p 47

Golec JR, Hu XP, Ray C, Woodley NE (2013) Strongygaster triangulifera (Diptera: Tachinidae) as a parasitoid of adults of the invasive Megacopta cribraria (Heteroptera: Plataspidae) in Alabama. J Entomol Sci 48:352-354

Görür G, Toper Kaygin A, Şenol Ö, Akyildirim Beğen H (2015) Cinara curvipes (Patch, 1912) (Hemiptera; Aphididae) as new aphid species for Turkish aphidofauna. Artvin Coruh Univ J For Fac 16:37-39

Grez AA, Zaviezo T, Roy H, Brown PMJ, Bizama G (2016) Rapid spread of Harmonia axyridis in Chile and its effects on ladybeetle biodiversity. Divers Distrib 22:982-994

Haelewaters D, Minnaar IA, Clusella-Trullas S (2016) First finding of the parasitic fungus Hesperomyces virescens (Laboulbeniales) on native and invasive ladybirds (Coleoptera: Coccinellidae) in South Africa. Parasite 23, 5, $4 \mathrm{pp}$

Haelewaters D, Zhao SY, Clusella-Trullas S, Cottrell TE, De Kesel A, Fiedler L, Herz A, Hesketh H, Hui C, Kleespies RG, Losey JE, Minnaar IA, Murray KM, Nedvĕd O, Pfliegler WP, Raak-van den Berg CL, Riddick EW, Shapiro-Ilan DI, Smyth RR, Steenberg T, van Wielink PS, Viglášová S, Zhao Z, Ceryngier P, Roy HE (2017) Parasites of Harmonia axyridis: current research and perspectives. Biocontrol 62:355-371

Hall RJ, Michie LJ, Ware RL (2009) First record of field parasitism of immature stages of the harlequin ladybird, Harmonia axyridis (Coleoptera: Coccinellidae), by the braconid wasp Dinocampus coccinellae (Hymenoptera: Braconidae). Entomol Rec J Var 121:57-58

Harding S, Poinar GO Jr, Dimitrova DV, Steenberg T (2011) Parasitylenchus sp. (Tylenchomorpha: Allantonematidae) parasitizing field populations of Harmonia axyridis (Coleoptera: Coccinellidae). Eur J Entomol 108:487-488
Harwood JD, Obrycki JJ (2005) Quantifying aphid predation rates of generalist predators in the field. Eur J Entomol 102:335-350

Harwood JD, Yoo HJS, Greenstone MH, Rowley DL, O'Neil RJ (2009) Differential impact of adults and nymphs of a generalist predator on an exotic invasive pest demonstrated by molecular gut-content analysis. Biol Invasions 11:895-903

Hautier L, Portugal FR, Hemptinne J-L, de Biseau J-C, Grégoire J-C (2013) Is Harmonia axyridis attacked by native species? IOBC-WPRS Bull 94:41-43

Herz A, Kleespies RG (2012) Occurrence of natural enemies in different populations of the invasive ladybird Harmonia axyridis (Pallas, 1771) (Coleoptera, Coccinellidae) in Germany. Mitt Dtsch Ges Allg Angew Ent 18:201-206

Hironori Y, Katsuhiro S (1997) Cannibalism and interspecific predation in two predatory ladybirds in relation to prey abundance in the field. Entomophaga 42:153-163

Hodek I, Evans EW (2012) Food relationships. In: Hodek I, van Emden HF, Honek A (eds) Ecology and behaviour of the ladybird beetles (Coccinellidae). Wiley-Blackwell, Chichester, pp 141-274

Hodek I, Honěk A (2009) Scale insects, mealybugs, whiteflies and psyllids (Hemiptera, Sternorrhyncha) as prey of ladybirds. Biol Control 51:232-243

Hoogendoorn M, Heimpel GE (2002) Indirect interactions between an introduced and a native ladybird beetle species mediated by a shared parasitoid. Biol Control 25:224-230

Hough-Goldstein J, Cox J, Armstrong A (1996) Podisus maculiventris (Hemiptera: Pentatomidae) predation on ladybird beetles (Coleoptera: Coccinellidae). Fla Entomol 79:64-68

Kajita Y, Obrycki JJ, Sloggett JJ, Haynes KF (2010) Intraspecific alkaloid variation in ladybird eggs and its effects on con- and hetero-specific intraguild predators. Oecologia 163:313-322

Katsanis A, Babendreier D, Nentwig W, Kenis M (2013) Intraguild predation between the invasive ladybird Harmonia axyridis and non-target European coccinellid species. Biocontrol 58:73-83

Katsoyannos P, Aliniazee MT (1998) First record of Strongygaster triangulifera (Loew) (Diptera: Tachinidae) as a parasitoid of Harmonia axyridis (Pallas) (Coleoptera: Coccinellidae) in western North America. Can Entomol 130:905-906

Kawauchi S (1984) Ecological studies on the natural enemies of Coccinella septempunctata brucki, Propylea japonica and Scymnus (Neopullus) hoffmanni (Coleoptera, Coccinellidae). Kurume Univ J 33:63-67 (in Japanese with summary in English)

Koch RL (2003) The multicolored Asian lady beetle, Harmonia axyridis: A review of its biology, uses in biological control, and non-target impacts. J Insect Sci 3:32, 16 pp

Koch RL, Galvan TL (2008) Bad side of a good beetle: the North American experience with Harmonia axyridis. Biocontrol 53:23-35

Koide T (1961) Observations on Perilitus coccinellae (Schrank). Gensei 1961(11):1-5

Koyama S, Majerus MEN (2008) Interactions between the parasitoid wasp Dinocampus coccinellae and two species 
of coccinellid from Japan and Britain. Biocontrol 53:253-264

Kuznetsov VN (1975) Fauna and ecology of coccinellids (Coleoptera, Coccinellidae) of the Primorye region. Trudy Biologo-pochvennogo instituta, new series 28:3-24 (in Russian)

Kuznetsov VN (1987) Parasites of coccinellids (Coleoptera, Coccinellidae) in the Far East. In: Ler PA, Storozheva NA (eds) New Data on systematics of the far east insects. DVO AN SSSR, Vladivostok, pp 17-22 (in Russian)

Kuznetsov VN (1997) Lady beetles of the Russian far east. Memoir No. 1, Center for systematic entomology, The Sandhill Crane Press, Inc., Gainsville, Florida

LaMana ML, Miller JC (1996) Field observations on Harmonia axyridis Pallas (Coleoptera: Coccinellidae) in Oregon. Biol Control 6:232-237

Liu CL (1950) Contribution to the knowledge of Chinese Coccinellidae. X. Occurrence of Perilitus coccinellae (Schrank), a parasite of adult Coccinellidae, in North China (Hymenoptera: Braconidae). Entomol News 61:207-208

Liu G (2001) A taxonomic study of Chinese Phorid Flies (Part I) (Diptera: Phoridae). NEU Press, Shenyang

Lombaert E, Guillemaud T, Cornuet J-M, Malausa T, Facon B, Estoup A (2010) Bridgehead effect in the worldwide invasion of the biocontrol harlequin ladybird. PLoS ONE 5(3): $\mathrm{e} 9743$

Lucas É (2012) Intraguild interactions. In: Hodek I, van Emden HF, Honek A (eds) Ecology and behaviour of the ladybird beetles (Coccinellidae). Wiley-Blackwell, Chichester, pp 343-374

Maeta Y (1969a) Some biological studies on the natural enemies of some coccinellid beetles. II. Phalacrotophora sp. Tohoku Konchu Kenkyu 4:1-6

Maeta Y (1969b) Biological studies on the natural enemies of some coccinellid beetles. I. On Perilitus coccinellae (Schrank). Kontyû 37:147-166 (in Japanese with summary in English)

Maure F, Doyon J, Thomas F, Brodeur J (2014) Host behaviour manipulation as an evolutionary route towards attenuation of parasitoid virulence. J Evolut Biol 27:2871-2875

Michalski M, Nadolski J, Marciniak B, Loga B, Bańbura J (2011) Faecal analysis as a method of nestling diet determination in insectivorous birds: a case study in blue tits Cyanistes caeruleus and great tits Parus major. Acta Ornithol 46:164-172

Michaud JP, Grant AK (2003) Intraguild predation among ladybeetles and a green lacewing: do the larval spines of Curinus coeruleus (Coleoptera: Coccinellidae) serve a defensive function? Bull Entomol Res 93:499-505

Michaud JP, Harwood JD (2012) Quantifying the impact of coccinellids on their prey. In: Hodek I, van Emden HF, Honek A (eds) Ecology and behaviour of the ladybird beetles (Coccinellidae). Wiley-Blackwell, Chichester, pp 465-487

Michie LJ, Disney RHL, Ware RL, Majerus MEN (2009) First occurrence of Phoridae (Diptera) and live Harmonia axyridis (Pallas) (Col.: Coccinellidae) eclosing from the same pupae. Entomol Rec J Var 121:68-69

Minnaar IA, Shinner R, Van Noort S, Clusella-Trullas S (2014) New records of the parasitic wasp Dinocampus coccinellae
(Hymenoptera: Braconidae) and its hosts in South Africa. Afr Entomol 22:226-229

Mostovski MB (2016) A review of scuttle fly genera of Israel (Diptera: Phoridae), with new records and an identification key. Zootaxa 4137(1):61-72

Nalepa CA, Kidd KA (2002) Parasitism of the multicolored Asian lady beetle (Coleoptera: Coccinellidae) by Strongygaster triangulifer (Diptera: Tachinidae) in North Carolina. J Entomol Sci 37:124-127

Nalepa CA, Kidd KA, Ahlstrom KR (1996) Biology of Harmonia axyridis (Coleoptera: Coccinellidae) in winter aggregations. Ann Entomol Soc Am 89:681-685

Naranjo SE, Hagler JR (2001) Toward the quantification of predation with predator gut immunoassays: a new approach integrating functional response behavior. Biol Control 20:175-189

Nechayev VA, Kuznetsov VN (1973) Avian predation on coccinellids in Primorye region. In: Ivliev LA (ed.) Entomofauna of the Soviet Far East, Trudy Biologo-pochvennogo Instituta 9 (112):97-98 (in Russian)

Nedvěd O, Kalushkov P, Fois X, Ungerová D, Rozsypalová A (2010) Harmonia axyridis: six-legged alligator or lethal fugu? IOBC/wprs Bull 58:65-68

Nedvěd O, Fois X, Ungerová D, Kalushkov P (2013) Alien vs. Predator-the native lacewing Chrysoperla carnea is the superior intraguild predator in trials against the invasive ladybird Harmonia axyridis. Bull Insectol 66:73-78

Noyes JS (2010) Encyrtidae of Costa Rica, 3. Subfamily Encyrtinae: Encyrtini, Echthroplexiellini, Discodini, Oobiini and Ixodiphagini, parasitoids associated with bugs (Hemiptera), insect eggs (Hemiptera, Lepidoptera, Coleoptera, Neuroptera) and ticks (Acari). Mem Am Entomol Inst 84:1-848

Noyes JS (2017) Universal Chalcidoidea Database. World Wide Web electronic publication. http://www.nhm.ac.uk/ chalcidoids. Accessed 9 May 2017

Orlova-Bienkowskaja MJ (2014) The outbreak of harlequin ladybird Harmonia axyridis (Pallas, 1773) (Coleoptera, Coccinellidae) in the Caucasus and possible sources of invasion. Russ J Biol Invasions 5:275-281

Orłowski G, Karg J (2013) Diet breadth and overlap in three sympatric aerial insectivorous birds at the same location. Bird Study 60:475-483

Osawa N (1992) Effect of pupation site on pupal cannibalism and parasitism in the ladybird beetle Harmonia axyridis Pallas (Coleoptera, Coccinellidae). Jpn J Entomol 60:131-135

Park HC, Park YC, Hong OK, Cho SY (1996) Parasitoids of the aphidophagous ladybeetles, Harmonia axyridis (Pallas) (Coleoptera: Coccinellidae) in Chuncheon areas, Korea. Korean J Entomol 26:143-147 (in Korean with English abstract)

Pasteels JM (2007) Chemical defence, offence and alliance in ants-aphids-ladybirds relationships. Popul Ecol 49:5-14

Pell JK, Baverstock J, Roy HE, Ware RL, Majerus MEN (2008) Intraguild predation involving Harmonia axyridis: a review of current knowledge and future perspectives. Biocontrol 53:147-168

Pettersson J (2012) Coccinellids and semiochemicals. In: Hodek I, van Emden HF, Honek A (eds) Ecology and behaviour of 
the ladybird beetles (Coccinellidae). Wiley-Blackwell, Chichester, pp 444-464

Phoofolo MW, Obrycki JJ (1998) Potential for intraguild predation and competition among predatory Coccinellidae and Chrysopidae. Entomol Exp Appl 89:47-55

Poinar GO Jr, Steenberg T (2012) Parasitylenchus bifurcatus $\mathrm{n}$. sp. (Tylenchida: Allantonematidae) parasitizing Harmonia axyridis (Coleoptera: Coccinellidae). Parasites and Vectors 5:218, 8 pp

Průchová A, Nedvěd O, Veselý P, Ernestová B, Fuchs R (2014) Visual warning signals of the ladybird Harmonia axyridis: the avian predators' point of view. Entomol Exp Appl 151:128-134

Raak-van den Berg CL, De Lange HJ, van Lenteren JC (2012) Intraguild predation behaviour of ladybirds in semi-field experiments explains invasion success of Harmonia axyridis. PLoS ONE 7(7): e40681, 11 pp

Raak-van den Berg CL, van Wielink PS, de Jong PW, Gort G, Haelewaters D, Helder J, van Lenteren JC (2014) Invasive alien species under attack: natural enemies of Harmonia axyridis in the Netherlands. Biocontrol 59:229-240

Riddick EW (2017) Spotlight on the positive effects of the ladybird Harmonia axyridis on agriculture. Biocontrol 62:319-330

Riddick EW, Cottrell TE, Kidd KA (2009) Natural enemies of the Coccinellidae: parasites, pathogens, and parasitoids. Biol Control 51:306-312

Romanowski J, Ceryngier P (2016) Invasive harlequin ladybird Harmonia axyridis preyed by Black redstart Phoenicurus ochruros. Kulon 21:78-80

Rondoni G, Comont RF, Ricci C, Roy HE (2013) Parasitization of coccinellid species in Oxfordshire and London and first record of an Harmonia axyridis-phorid association from Italy. In: Book of abstracts, international symposium ecology of Aphidophaga12, Belgrade - Serbia, September 9-12, 2013, p 81

Roy HE, Brown PMJ, Rothery P, Ware RL, Majerus MEN (2008) Interactions between the fungal pathogen Beauveria bassiana and three species of coccinellid: Harmonia axyridis, Coccinella septempunctata and Adalia bipunctata. Biocontrol 53:265-276

Roy HE, Lawson Handley LJ, Schönrogge K, Poland RL, Purse BV (2011a) Can the enemy release hypothesis explain the success of invasive alien predators and parasitoids? Biocontrol 56:451-468

Roy HE, Rhule E, Harding S, Lawson Handley L-J, Poland RL, Riddick EW, Steenberg T (2011b) Living with the enemy: parasites and pathogens of the ladybird Harmonia axyridis. Biocontrol 56:663-679

Roy HE, Brown PMJ, Frost R, Poland RL (2011c) The Ladybirds (Coccinellidae) of Britain and Ireland. FSC Publications, Shrewsbury

Roy HE, Adriaens T, Isaac NJB, Kenis M, Onkelinx T, San Martin G, Brown PMJ, Hautier L, Poland R, Roy DB, Comont R, Eschen R, Frost R, Zindel R, Van Vlaenderen J, Nedvěd O, Ravn HP, Grégoire J-C, de Biseau J-C, Maes D (2012) Invasive alien predator causes rapid declines of native European ladybirds. Divers Distrib 18:717-725

Roy HE, Brown PMJ, Adriaens T, Berkvens N, Borges I, Clusella-Trullas S, Comont RF, De Clercq P, Eschen R, Estoup A, Evans EW, Facon B, Gardiner MM, Gil A, Grez AA,
Guillemaud T, Haelewaters D, Herz A, Honek A, Howe AG, Hui C, Hutchison WD, Kenis M, Koch RL, Kulfan J, Lawson Handley L, Lombaert E, Loomans A, Losey J, Lukashuk AO, Maes D, Magro A, Murray KM, San Martin G, Martinkova Z, Minnaar IA, Nedvěd O, Orlova-Bienkowskaja MJ, Osawa N, Rabitsch W, Ravn HP, Rondoni G, Rorke SL, Ryndevich SK, Saethre M-G, Sloggett JJ, Soares AO, Stals R, Tinsley MC, Vandereycken A, van Wielink P, Viglášová S, Zach P, Zakharov IA, Zaviezo T, Zhao Z (2016) The harlequin ladybird, Harmonia axyridis: global perspectives on invasion history and ecology. Biol Invasions 18:997-1044

San Martin G (2017) Meta-analysis of the parasitism levels of the invasive ladybird Harmonia axyridis. https://figshare. com/s/5d1a0d38be7d0941a455. https://doi.org/10.6084/ $\mathrm{m} 9$. figshare. 5336560

Santi F, Maini S (2006) Predation upon Adalia bipunctata and Harmonia axyridis eggs by Chrysoperla carnea larvae and Orius laevigatus adults. Bull Insectol 59:53-58

Sato S, Dixon AFG (2004) Effect of intraguild predation on the survival and development of three species of aphidophagous ladybirds: consequences for invasive species. Agric For Entomol 6:21-24

Shapiro-Ilan DI, Cottrell TE (2005) Susceptibility of lady beetles (Coleoptera: Coccinellidae) to entomopathogenic nematodes. J Invertebr Pathol 89:150-156

Sloggett JJ (2010a) Predation of ladybird beetles by the orb-web spider Araneus diadematus. Biocontrol 55:631-638

Sloggett JJ (2010b) Colour pattern polymorphism and chemical defence in Harmonia axyridis. IOBC/wprs Bull 58:115-123

Sloggett JJ (2013) Comment on "Invasive harlequin ladybird carries biological weapons against native competitors". Science 341:1342-d

Sloggett JJ, Magro A, Verheggen FJ, Hemptinne J-L, Hutchison WD, Riddick EW (2011) The chemical ecology of Harmonia axyridis. Biocontrol 56:643-661

Sluss R (1968) Behavioral and anatomical responses of the convergent lady beetle to parasitism by Perilitus coccinellae (Schrank) (Hymenoptera: Braconidae). J Invertebr Pathol 10:9-27

Solter LF, Kyei-Poku GK, Johny S (2013) Comment on "Invasive harlequin ladybird carries biological weapons against native competitors". Science 341:1342-c

Steenberg T, Harding S (2009) The harlequin ladybird (Harmonia axyridis Pallas) in Denmark: spread and phenology during the initial phase of invasion. Ent Meddr 77:27-39

Steenberg T, Harding S (2010) The harlequin ladybird (Harmonia axyridis) in Denmark: spread, phenology, colour forms and natural enemies in the early phase of establishment. IOBC/wprs Bull 58:143-147

Taucare-Ríos A, Mardones D, Zúñiga-Reinoso Á (2016) Steatoda nobilis (Araneae: Theridiidae) in South America: a new alien species for Chile. Can Entomol 148:479-481

Togni PHB, Souza LM, Sicsú PR, Costa VA, Amaral DSSL, Franco AC, Sujii ER, Venzon M (2015) Coccinellidae parasitoids in Brazil: neglected species in a mega-diverse country. Neotrop Entomol 44:528-532

Triltsch H (1996) On the parasitization of the ladybird Coccinella septempunctata L. (Col., Coccinellidae). J Appl Entomol 120:375-378 
Trjapitzin VA (2011) On species of the genus Homalotylus Mayr, 1876 (Hymenoptera: Encyrtidae) from the Russian Far East. Far East Entomol 231:1-4

Trjapitzin VA (2013) Homalotylus hemipterinus (De Stefani, 1898) (Hymenoptera: Encyrtidae) in the Russian Far East. Far East Entomol 268:9-12

Ukrainsky AS, Orlova-Bienkowskaja MJ (2014) Expansion of Harmonia axyridis Pallas (Coleoptera: Coccinellidae) to European Russia and adjacent regions. Biol Invasions 16:1003-1008

Veselý P, Ernestová B, Nedvěd O, Fuchs R (2016) Do predator energy demands or previous exposure influence protection by aposematic coloration of prey? Curr Zool 63:259-267

Vilcinskas A, Stoecker K, Schmidtberg H, Röhrig CR, Vogel H (2013) Invasive harlequin ladybird carries biological weapons against native competitors. Science 340:862-863

Vilcinskas A, Schmidtberg H, Estoup A, Tayeh A, Facon B, Vogel H (2015) Evolutionary ecology of microsporidia associated with the invasive ladybird Harmonia axyridis. Insect Sci 22:313-324

Vogel H, Schmidtberg H, Vilcinskas A (2017) Comparative transcriptomics in three ladybird species supports a role for immunity in invasion biology. Dev Comp Immunol $67: 452-456$
Ware RL, Majerus MEN (2008) Intraguild predation of immature stages of British and Japanese coccinellids by the invasive ladybird Harmonia axyridis. Biocontrol 53:169-188

Ware R, Michie L-J, Otani T, Rhule E, Hall R (2010) Adaptation of native parasitoids to a novel host: the invasive coccinellid Harmonia axyridis. IOBC/wprs Bull 58:175-182

Wells PM, Baverstock J, Clark SJ, Jiggins FM, Roy HE, Pell JK (2017) Determining the effects of life stage, shared prey density and host plant on intraguild predation of a native lacewing (Chrysoperla carnea) by an invasive coccinellid (Harmonia axyridis). Biocontrol 62:373-384

Yasuda H, Kimura T (2001) Interspecific interactions in a tritrophic arthropod system: effects of a spider on the survival of larvae of three predatory ladybirds in relation to aphids. Entomol Exp Appl 98:17-25

Yasuda H, Ohnuma N (1999) Effect of cannibalism and predation on the larval performance of two ladybird beetles. Entomol Exp Appl 93:63-67

Yasuda H, Evans EW, Kajita Y, Urakawa K, Takizawa T (2004) Asymmetric larval interactions between introduced and indigenous ladybirds in North America. Oecologia 141:722-731 